\title{
Mil mundos en un mundo: imagen e imaginación política en la prensa marginal madrileña, 1968-1978
}

\section{A thousand worlds within a world: image and political imagination in the Madrilenian marginal press, 1968-1978}

\author{
Inés Molina Agudo \\ Universitat Autònoma de Barcelona
}

Fecha de recepción: 30 de octubre de 2018

Fecha de aceptación: 19 de diciembre de 2018
Anuario del Departamento de Historia y Teoría del Arte vol. 29-30, 2017-2018, pp. 93-120 ISSN: 1130-5517, eISSN: 2530-3562

http://doi.org/10.15366/anuario2017-2018.29-30.04

\begin{abstract}
RESUMEN
El presente trabajo examina el fenómeno de la prensa marginal madrileña, las producciones editoriales clandestinas que circulaban en la ciudad de Madrid durante los primeros años de la Transición democrática. Partiendo de los Mayos globales y las reflexiones sobre los medios de comunicación que estos impulsaron, se trazará una genealogía de prácticas, miradas y estrategias de subversión que dan forma a la prensa libre, vinculándola con el desarrollo de la prensa marginal durante la década de los 70 en Madrid. Al mismo tiempo, este trabajo se presenta como una tentativa teórico-metodológica que toma la mirada y la imagen como herramientas analíticas de gran potencial epistemológico para el estudio de la Transición española.
\end{abstract}

\section{PALABRAS CLAVE}

Prensa marginal madrileña. Imaginación política. Contracultura. Transición española. Mass media. Sociedad de consumo. Mayos globales.

\begin{abstract}
The present article examines the phenomenon of the Madrilenian marginal press, the clandestine editorial productions circulating in Madrid during the first years of the democratic transition. Starting from the Global Sixties and the reflections on the mass media motivated by the new movements, this paper traces a genealogy of practices, perspectives and strategies of subversion that shape the free press, linking it with the development of the Madrilenian marginal press during the $70 \mathrm{~s}$. At the same time, this work is presented as a theoretical-methodological attempt that takes the look and the image as analytical tools of great epistemological potential for the study of the Spanish Transition.
\end{abstract}

\section{KEY WORDS}

Madrilenian marginal press. Political imagination. Counterculture. Spanish transition. Mass media. Consumer society. Global Sixties. 


\section{Introducción ${ }^{1}$}

Y por ahí, entrelazados con los mil mundos que conforman el mundo, una parte más, unos papeles más. [...] Unas fotocopias repletas de textos ininteligibles (no se leen muchas veces), de un grafismo barato-no profesional-no bello. Eso es la prensa marginal, esfuerzos que caen como un rocío negro sobre la hedionda ciudad que los vomitó hacia lo alto, hacia fuera²

El estudio de las manifestaciones contraculturales o periféricas, en el contexto de la Transición democrática española, viene explorándose de forma atenta y rigurosa por parte de un número creciente de investigadores, curadores y artistas en las últimas décadas ${ }^{3}$. Entre estos, cabe destacar el papel que han desempeñado, en el seno de la disciplina histórica académica, las recientes investigaciones de Germán Labrador Méndez, quien ha elaborado análisis ampliamente informados sobre la intersección entre la literatura contracultural y los procesos de democratización y apertura de los espacios de vida llevados a cabo por los sectores populares en el último franquismo ${ }^{4}$. En sus trabajos, Labrador perfila lo que ha dado en denominar una "historiografía cívica", que amplía y matiza los enfoques metodológicos empleados en el estudio de la época transicional, poniendo en su centro las experiencias vitales de las personas que la habitaron:

Una historia al servicio de la ciudadanía debe salvaguardar la experiencia humana, lo que es como decir su punto de vista. Y debe disociar, en consecuencia, el estudio de las tecnologías políticas [...] respecto de las vidas de aquellos regidos por las mismas ${ }^{5}$.

El presente artículo recupera el proyecto metodológico elaborado por Labrador y lo traslada al campo del análisis visual, proponiéndose examinar el fenómeno de la llamada "prensa marginal madrileña": las producciones editoriales clandestinas, carentes de depósito legal ${ }^{6}$, que circularon en la ciudad de Madrid entre 1975 y 1978. Las imágenes de la prensa marginal madrileña serán comprendidas, a lo largo del presente texto, como índices visuales de un proyecto estético-político alternativo al del reformismo franquis-

\footnotetext{
1 Esta investigación fue presentada como Trabajo de Fin de Máster en septiembre de 2018, en el marco del Máster de Historia del Arte Contemporáneo y Cultura Visual (UAM-UCM-MNCARS). Su elaboración ha sido posible gracias a una amplia red de personas a quienes quiero ofrecer mi más sincero agradecimiento: en primer lugar, a mi tutora Noemí de Haro y a Sergio Vega, por sus comentarios y orientación; a Paula, Elisa y José Ramón, por descubrirme La Prospe y la buhardilla repleta de revistas empolvadas; a Alberto García-Alix y a Pilar, por mostrarme aquella maleta duchampiana; y a Pepe Ribas, por abrirme su casa y su archivo. También a Germán Labrador y a Pablo Dopico, por sus generosas sugerencias mediadas por un furtivo correo electrónico.

2 J.M. Costa, "La PMM (Prensa Marginal Madrileña). Una alucinación colectiva", Ajoblanco Extra "Prensa Marginal”, s.n. (octubre de 1978). p. 3.

3 La producción es, afortunadamente, desbordante. Mencionamos algunos de los trabajos más significativos: Teresa VILARÓs, El mono del desencanto. Una crítica cultural de la transición española (1973-1993), Madrid, Siglo XXI, 1998; Cristina MoReIRAS, Cultura herida. Literatura y cine en la España democrática, Madrid, Ediciones Libertarias, 2002; Pablo Carmona Pascual, "Libertarias y contraculturales: el asalto a la sociedad disciplinaria. Entre Barcelona y Madrid 1965-1979", Tesis doctoral, Madrid, Universidad Complutense de Madrid, 2012; Juan AlBARrÁn (ed.), Arte y transición, Madrid, Brumaria, 2012; Patricia MAYAYO y Jorge Luis MARzo, Arte desde 1900. Modernidad, antimodernidad, posmodernidad, Madrid, Akal, 2015; Madrid Activismos (1968-1982), Alberto Berzosa (comis.), Madrid, La Casa Encendida (catálogo de la exposición celebrada del 1 de julio al 18 de septiembre de 2016), 2016. También la colección Desacuerdos, en sus volúmenes 3, 4, 5 y 7 (2005-2017), ha recogido el análisis de las producciones contraculturales en el contexto español.

${ }^{4}$ Germán Labrador, Letras arrebatadas. Poesía y química en la transición española, Madrid, Devenir Ensayo, 2009; Germán LABRADOR, Culpables por la literatura. Imaginación política y contracultura en la transición española (1968-1986), Madrid, Akal, 2017.

5 LABRADOR, 2017, p. 83.

${ }^{6}$ La Ley de Prensa (1966), impulsada por el ministro reformista Manuel Fraga Iribarne, eliminó la censura preventiva vigente desde 1938, si bien dejaba estipulada la posibilidad de sufrir coacción política por parte del régimen a posteriori, si los contenidos eran contrarios a sus principios. De esta forma, los editores de publicaciones que pudieran ser consideradas problemáticas optaban por prescindir de su depósito legal, estipulado por la ley, con el fin de evitar problemas con el Tribunal de Orden Público. Véase Giulia QuAgGio, La cultura en transición. Reconciliación y politica cultural en España, 1976-1986, Madrid, Alianza, 2014, pp. 47-48.
} 
ta, emanaciones de una imaginación política concreta y distinta: aquella de las comunidades "enrolladas"7 o alternativas gestadas en el Madrid de la década de los 70, epicentro del régimen y baluarte de sus políticas represivas, cristalizadas jurídicamente en la Ley de Peligrosidad Social (1970). De este modo, el análisis visual de los documentos se movilizará de manera relacional y situada, buscando vincular los proyectos de la prensa marginal con un análisis de sus modos de organización, producción y distribución, así como de las maneras de estar en el mundo de aquellos sujetos que les dieron forma (fig. 1).

La argumentación desplegada en las siguientes páginas se ha configurado a partir de la recopilación de fuentes primarias (fanzines, revistas, actas y correspondencia) en archivos públicos y privados, y de la ejecución de entrevistas a distintos agentes de la época, directa o indirectamente vinculados a estos proyectos editoriales. Estos materiales han sido abordados desde el prisma teórico de los Estudios Visuales ${ }^{8}$, interrogando a las imágenes de la prensa marginal desde nuestra actualidad en calidad de sedimentos de experiencia sepultados por las arquitecturas historiográficas hegemónicas. Mirar las imágenes como inscripciones que dan forma al presente nos permite historizar desde un ángulo distinto e insospechado: movilizamos, con ellas, el estudio de la codificación visual de la experiencia, aquella experiencia que no se puede nombrar, que solo se puede mostrar. Mientras el acontecimiento es el "qué", la imagen se revela el "cómo" del mismo, emergiendo en esta polaridad la tensión inmanente entre el acontecimiento y el relato9.

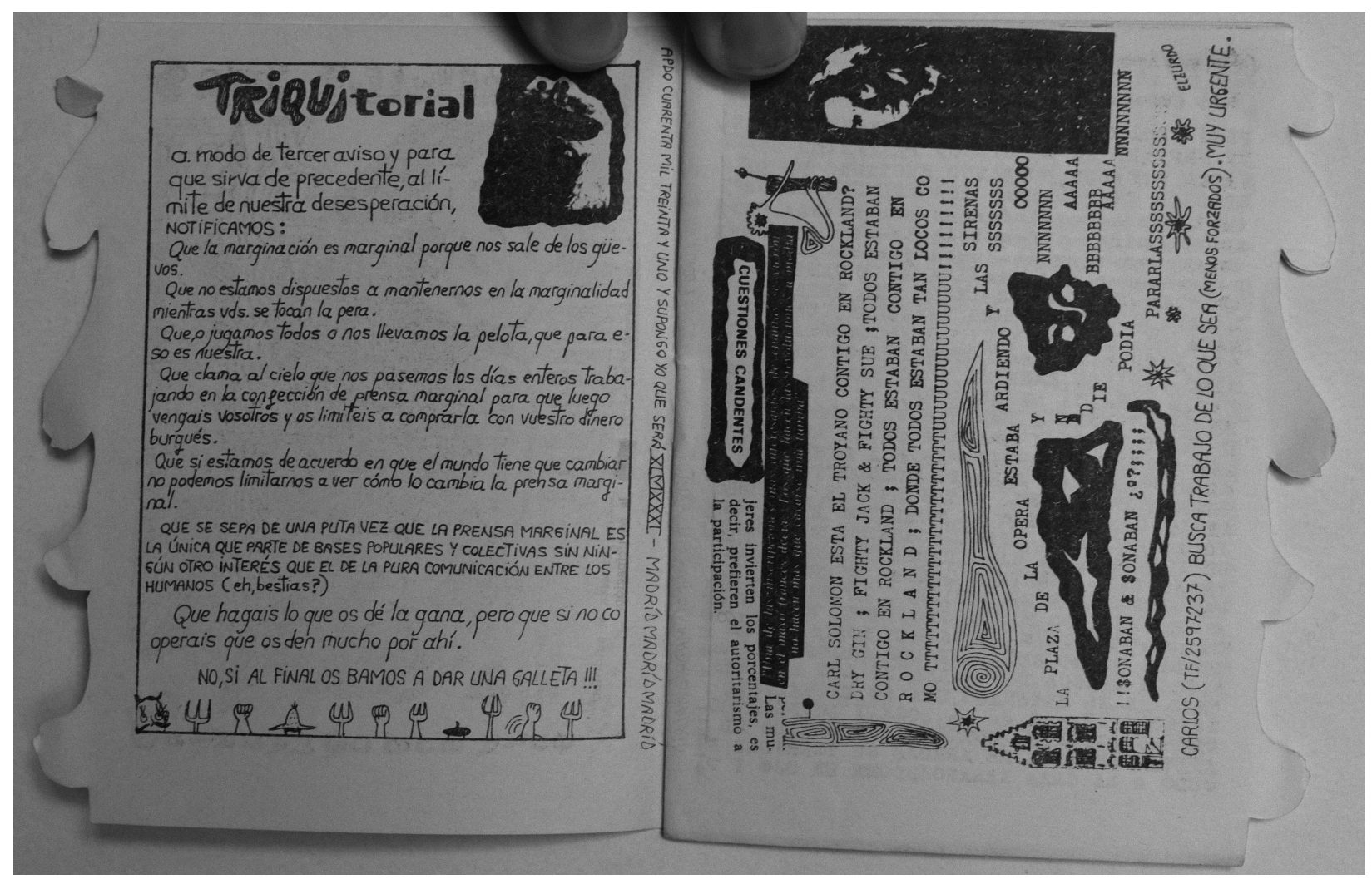

Fig. 1. Equipo Antípodas, “Trikitorial”, Mmmuá nº 6, Madrid, 1977, archivo personal de Alberto García-Alix.

\footnotetext{
7 Jesús Ordovás, De qué va el Rrollo, Madrid, Ediciones La Piqueta, 1977.

${ }^{8}$ Nos fundamentamos, esencialmente, en las propuestas teóricas elaboradas por Susan BuCK-Morss, "Estudios Visuales e imaginación global", Antípoda, 9 (2009), pp. 19-46; George DiDI-Huberman, Cuando las imágenes tocan lo real, Madrid, Círculo de Bellas Artes, 2013; y W.T.J. Mitchell, "Mostrando el ver: una crítica de la cultura visual”, Revista de Estudios Visuales, vol. 1 (2003), pp. 17-40.

9 Para profundizar en estas reflexiones, consultar el texto de Sergio RoJAs, "La visualidad de lo fatal: historia e imagen", en N. Richard y A. Moreiras (eds.), Pensar en/la postdictadura, Santiago, Editorial Un cuarto Propio, 2001, pp. $285-298$.
} 
Los acercamientos a la prensa disidente ${ }^{10}$ de la época transicional desde las epistemologías de la imagen se revelan aún como una tarea inconclusa. Si bien estos han sido desarrollados productivamente en el campo del cine y la cultura audiovisual ${ }^{11}$, la prensa marginal ha sido apenas atendida en su especificidad, siendo generalmente apelada en tanto que ilustración o apéndice visual de análisis más amplios ${ }^{12}$. Así, este artículo pretende invitar a profundizar en nuevas aproximaciones a estas producciones editoriales, con el fin de ponerlas en relación con las transformaciones de la esfera pública y mediática que apuntalaron el reacomodamiento del sistema político español acontecido en la Transición democrática.

La cronología aquí trazada abarca la década comprendida entre 1968 y 1978. El 68, sin embargo, se quiere presentar como una coordenada histórica constelada de prácticas, estrategias y subjetividades localizadas en contextos específicos, que en ocasiones exige retrotraerse a fechas anacrónicamente anteriores o posteriores al célebre año del Mayo francés. Las propuestas estético-políticas de la prensa marginal madrileña serán ligadas a las experiencias comunicativas desarrolladas durante los Mayos globales, esbozando una genealogía de prácticas apenas explorada en el contexto español. La horquilla temporal se cierra en 1978, cuando la deriva política de la Transición transforme la esfera pública y mediática de la sociedad española. A partir de 1977 los pactos sociales y económicos, así como la aguda crisis económica global, precipitan el proceso de desactivación de la movilización civil y, con ella, las experiencias comunitarias que alumbraron la prensa marginal madrileña, dando paso a lo que Pablo Carmona ha llamado el "carnaval capturado": la cooptación de las estrategias de transgresión alumbradas en la década anterior, cristalizadas en la Movida madrileña, por parte de la industria y la política culturales ${ }^{13}$.

En el primer apartado se argumentará la conveniencia de problematizar la noción de "imaginación política" en el contexto de las revueltas del ciclo del 68, y de inscribirla en el estudio histórico de la Transición española, incidiendo en las estrategias comunes o afines entre la prensa marginal madrileña y otras publicaciones extranjeras. En un segundo momento, se analizarán los debates en torno a los medios de comunicación en la España coetánea, trazando un hilo de continuidad entre el antifranquismo y los proyectos de la prensa marginal que despuntarán en la década de los 70 y tomando como eje articulador la experimentación en el campo de la historieta. Por último, en las tres últimas secciones se analizará el fenómeno de la prensa marginal madrileña atendiendo a tres matrices de lectura: (1) las estrategias de subversión simbólica y visual empleadas por la prensa marginal madrileña, (2) las "geografías secretas" de la ciudad de Madrid plasmadas en la prensa marginal y (3) la auto-organización comunitaria vinculada a los nuevos proyectos editoriales.

10 A lo largo del texto utilizaremos las nociones de "prensa disidente" o "antiautoritaria" como nociones intercambiables, aludiendo con ello a aquellas publicaciones que expresaban un punto de vista crítico y subversivo respecto al régimen, entre las cuales encontraríamos las producciones específicas de la prensa marginal madrileña. Nos apoyamos, por ejemplo, en el dossier de prensa libertaria elaborado por la revista La Bicicleta en 1978. El dossier caracteriza a estas producciones como "esfuerzos por una alternativa a la información vertical y autoritaria, solo ahí el lector-receptor también participa con cartas, dibujos, artículos... acogiendo la creatividad anónima". En él, se mezcla "prensa marginal, cómix, acracia y marginación militante, pinitos artísticoliterarios y equipos autogestionarios aventurados en la comercialización como el que estás leyendo"11, y encontramos desde cómix marginales como Bazofia, revistas feministas como Mujeres Libres o Vindicación Feminista, la plataforma editorial LGTB Nosotros, proyectos de arte y literatura como Collages/L Cloaca o las publicaciones vinculadas a los barrios y ateneos como Barrio Libertario, producido por el Ateneo de Lavapiés-Latina-Embajadores en Madrid. Ver VVAA, "Dossier de prensa libertaria", La Bicicleta, s.n. (octubre de 1978), p. 28-55.

11 Véase, a modo de contundente muestra, el trabajo de Alberto BERZosA, Homoherejías filmicas: cine homosexual y subversivo en España en los años setenta y ochenta, Madrid, Brumaria, 2014.

12 En este sentido, cabe señalar la gran importancia que Labrador Méndez otorga a las imágenes de la prensa contracultural en sus estudios, cuajando sus análisis de documentación gráfica y fotográfica de la época. Véase LABRADOR, $2009 ; 2017$.

13 En su texto, Carmona argumenta cómo la imposibilidad de generar estructuras productivas autónomas hace que las instituciones municipales se conviertan en las patrocinadoras más deseables del momento para las experiencias culturales comunitarias, y señala a los grandes homenajes a La Movida, como las exposiciones "Madrid, Madrid, Madrid" o "Crónicas de Juventud", como buenos ejemplos de estos sucesos. Véase Pablo CARMOnA PASCUAL, "La pasión capturada. Del carnaval underground a 'La Movida madrileña', marca registrada”, en Desacuerdos 5, Sevilla, UNIA/MACBA/MNCARS/Arteleku/Centro José Guerrero-Diputación de Granada, 2009, pp. 147-158. 
En definitiva, esta investigación ha intentado responder a los siguientes interrogantes: ¿cuál es el potencial epistemológico de las imágenes en el estudio y desentramado de las "otras transiciones"14?, ¿de qué manera, siguiendo a Labrador, se puede elaborar una "historiografía cívica" desde la imagen?, ¿es productivo actualizar las lecturas críticas de la esfera mediática transicional?, ¿fue la centralidad de los medios de comunicación en el proceso transicional pensada y apuntalada desde el terreno de los medios impresos disidentes? Si bien este texto es el resultado de una investigación aún precoz, esperamos poder ofrecer un repertorio de posibles puntos de fuga suficientemente atractivo y contundente.

\section{Sobre imaginación política y medios de comunicación alternativos}

A lo largo de la década de los 60, al calor de la expansión de las sociedades de consumo en el occidente capitalista, comienzan a despuntar las movilizaciones sociales que darán cuerpo al ciclo sesentayochista en distintos puntos geográficos. Como señala Germán Labrador,

[...] por vía del ocio o de la utopía, por el camino del consumo o el de la política, a finales de los años sesenta, en los países del bloque capitalista, incluyendo la periferia ibérica, la discusión sobre las formas de trabajo y el reparto del tiempo anima demandas no solo a favor de mejoras laborales, sino, de pronto, también en pos de una vida nueva ${ }^{15}$.

Estas demandas de "vida nueva", que también penetraron las fronteras del Estado español 16, vinieron articuladas por una voluntad colectiva de transformación radical del sistema de valores establecido (fig. 2). Frente a un régimen capitalista fordista, alienante y monótono, el horizonte socialista en su declinación soviética y autoritaria tampoco parecía ofrecer perspectivas más deseables. La imaginación se anhelaba en el poder, en tanto que se erigía como la capacidad fundamental para construir nuevas maneras de vivir. Siguiendo a Jordi Maiso, contra una vida gris, devenida segunda naturaleza, la imaginación parecía capaz de dar forma a un afuera del capitalismo, una utopía urgente e inmediata ${ }^{17}$. En este sentido, la noción de "imaginación política", que guió en mayor medida el último trabajo de Labrador Méndez ${ }^{18}$, se nos devuelve como un prisma de lectura privilegiado para la comprensión de los ciclos de lucha del 68 y sus posteriores desarrollos. Lejos de ser una facultad abstracta y desrealizada, carente de consecuencias materiales, la imaginación política es aquí comprendida como el ejercicio colectivo de la fantasía, fundador de modos de vida y de acción comunes ${ }^{19}$.

"Toda la prensa es tóxica", rezaba el cartel producido por el Atelier Populaire en el París del Mayo, "lean los folletos, los carteles, el periódico mural" (fig. 3). Dentro de estos "afueras" posibles, activados por la imaginación política del 68, cabe detenerse en la crítica hacia los mass media, clave de bóveda de la sociedad del espectáculo debordiana, y en la construcción de canales alternativos y emancipadores de comunicación por parte de los movimientos sociales ${ }^{20}$. Estas publicaciones alternativas buscaban

\footnotetext{
14 Sobre la cuestión de las "otras transiciones", ampliamente trabajada en la esfera académica y activista, véase la publicación resultante del congreso homónimo (Barcelona, 24 y el 25 de febrero de 2017), Fundación Salvador Seguí (ed.), Las otras protagonistas de la transición. La izquierda radical y los movimientos sociales, Madrid, Brumaria, 2018.

15 LABrador, 2017, p. 58.

16 Sobre la difusión de los acontecimientos del 68 en la España tardofranquista véase, por ejemplo, la publicación de Patricia Badenes Salazar, Fronteras de papel. El Mayo francés en la España del 68, Madrid, Cátedra, 2018.

17 Jordi MAISO, ¿Más allá del principio de realidad? Un diagnóstico sobre imaginación, poder y utopía a partir de tres citas” en M. Cabot, L. Lastoria y A. Zuin, Tecnología, violencia y memoria, Madrid, Anthropos, 2018, p. 206.

18 Tal y como explicita en su introducción, el historiador comprende los materiales literarios analizados en él como parte de los "archivos de la imaginación política" transicional, archivos de deseo, formas de vida, ficción o imaginación hecha materia. En LABRADOR, 2018, p. 58.

19 Ariella Azoulay, Civil Imagination, Londres, Verso, 2015.

20 Kristin Ross, Mayo del 68 y sus vidas posteriores, Madrid, Antonio Machado, 2008, pp. 347-405.
} 


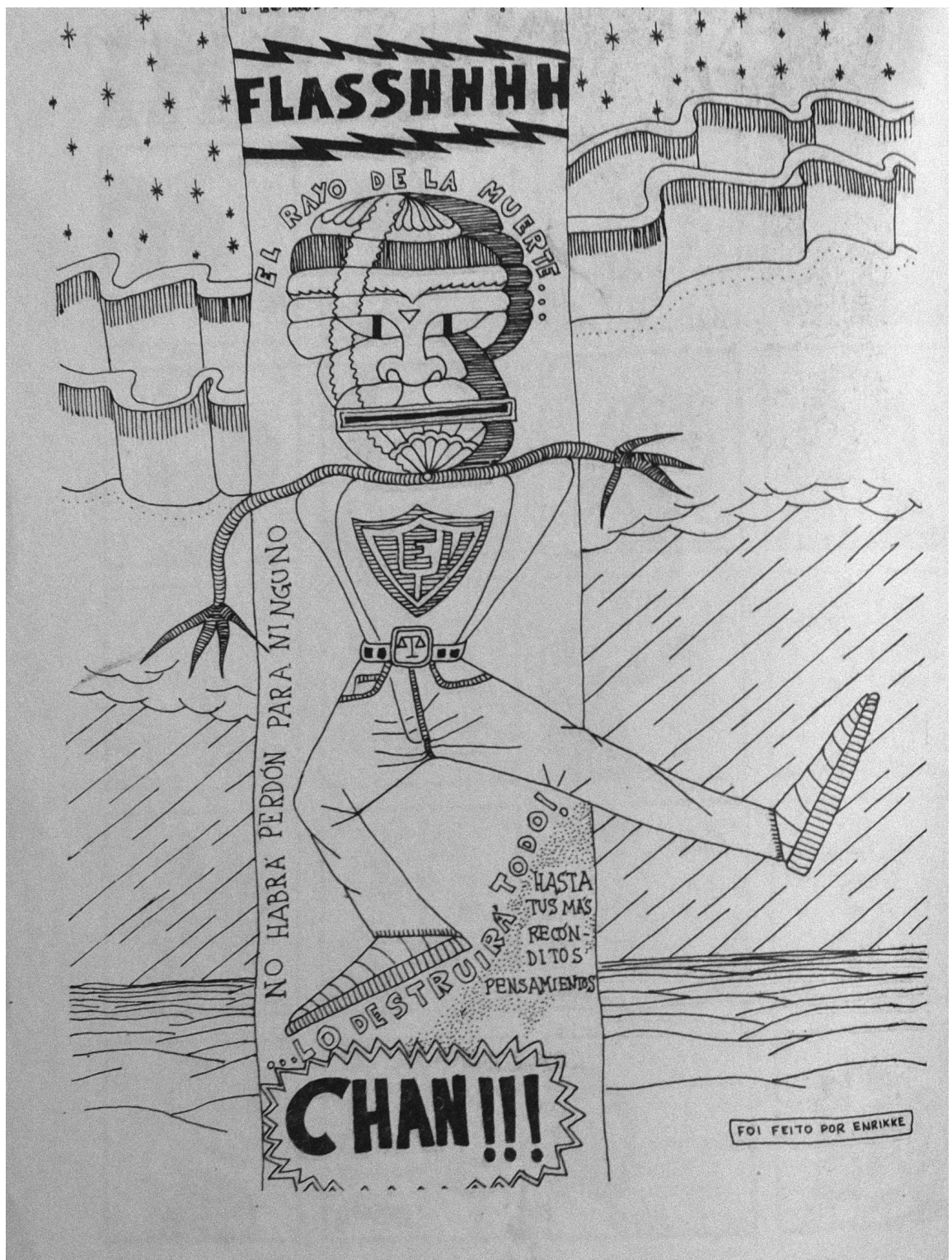

Fig. 2. Enrikke, “Flasshhhh”, Talami s.n., Madrid, 1977, archivo personal de Alberto García-Alix.

desmontar el corporativismo y la verticalidad de los medios de comunicación establecidos. En ellas la imagen profesional, limpia y transparente de la prensa comercial ${ }^{21}$ se vio reemplazada por la diversidad y la densidad visual, haciendo uso de la serigrafía, la ilustración, el collage o la fotografía (fig. 4). Los cuerpos de texto se mostraban desordenados, amontonándose a lo largo de las páginas en una suerte de tumulto gráfico, encumbrando la protesta como argumento visual en sí mismo. Recuperando los observaciones de Lorraine Wild, esta prensa alternativa se articuló en torno a la "agencia y la urgencia", localizando las

21 En su estudio sobre los medios de comunicación en la Transición española, Juan Pecourt recupera los análisis de Pierre Bourdieu para delimitar el "campo comercial" de la cultura en la década de los 70, en el que operaban los agentes que se dirigían a un público masivo, y que "procuraba las plataformas necesarias para la difusión de las ideas centristas y conservadoras, es decir, facilitaba los canales de comunicación para transmitir los discursos de la continuidad y la reforma”, en Juan PECOURT, “Activismo, medios y transición política", en J. Albarrán (ed.), Arte y transición, Madrid, Brumaria, 2012 p. 180. 
herramientas que posibilitaban una comunicación rápida y eficaz: la máquina de escribir IBM Selectric, el mimeógrafo, la litografía off-set o la tipografía manual se convirtieron en recursos que daban agencia a la disidencia global durante los años sesenta, que "intentaba transmitir una cosmovisión radicalmente nueva a través del poder de las imágenes y el texto"22 (fig. 5). En última instancia se buscaba "liberar" la comunicación de los constreñimientos del profesionalismo, el corporativismo y la verticalidad de los medios comerciales, desencadenando una comunicación efectiva entre la gente.

Una experiencia pionera y consolidada en el terreno de los medios impresos liberados fue la del Underground Press Syndicate (1966-1978) -en 1973 cambiará su nombre por "Alternative Press Syndicate", ya que se consideró que sus publicaciones comparecían en igualdad de condiciones en el espacio público-, una plataforma de apoyo e intercambio que aglutinaba a una serie de los medios independientes en los Estados Unidos (fig. 6). El sindicato, fundado por cinco publicaciones under, The East Village Other, Los Angeles Free Press, The Berkeley Barb, The Paper y el Fifth Estate, contaba, hacia 1971, con más de 270 miembros. Las distintas publicaciones funcionaban de manera asamblearia, articulándose a través de procesos comunitarios y abiertos de producción y distribución que buscaban romper con la frontera infranqueable entre el emisor y el receptor marcada por los medios oficiales. Es interesante, en este sentido, rastrear el retrato gráfico que de los medios generalistas se hacía desde estas publicaciones. La portada del Berkeley Barb que aquí presentamos (fig. 7), a modo de ejemplo, denunciaba la represión y la violencia institucional ejercida contra el movimiento hippie a través de la reproducción de los propios titulares de la prensa convencional y su diseminación alea-

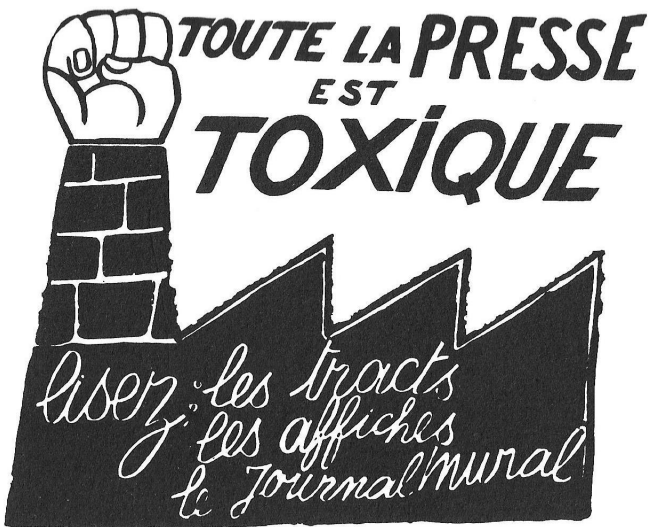

Fig. 3. Atelier Populaire, "Toute la presse est toxique" ("Toda la prensa es tóxica"), Mayo de 1968, serigrafía, París.

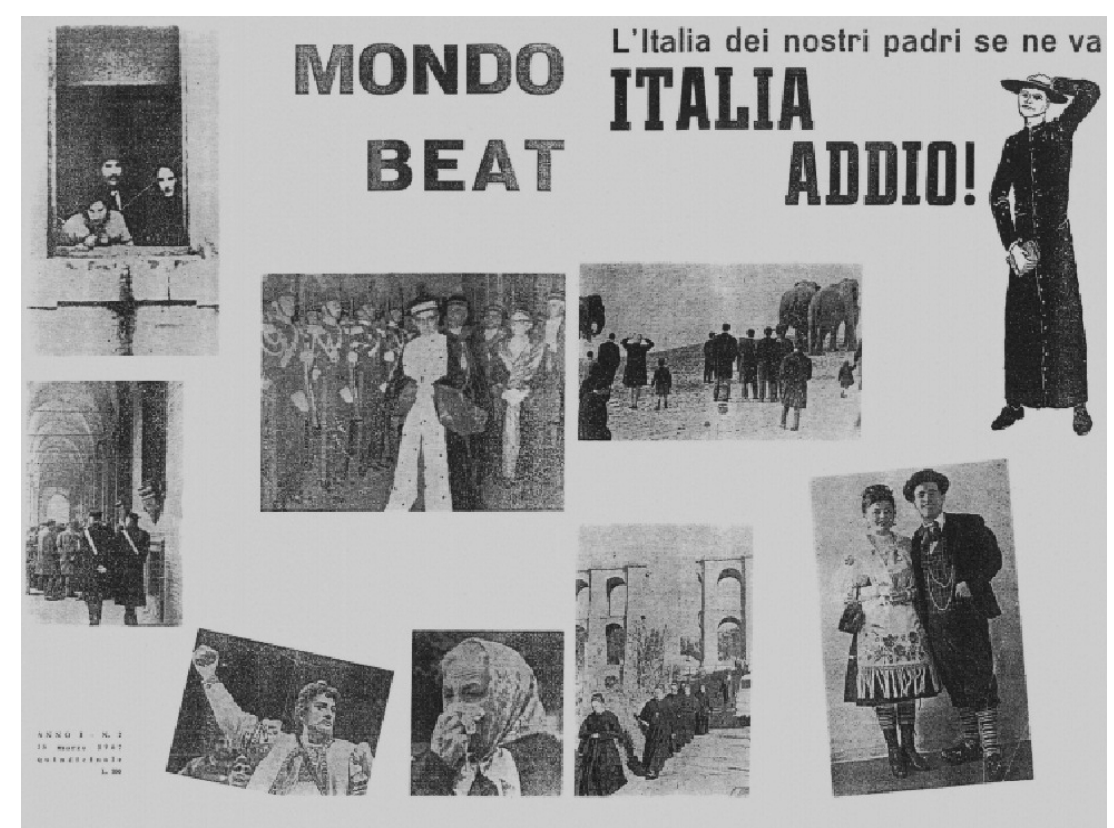

Fig. 4. Portada y contraportada de Mondo Beat $\mathrm{n}^{\circ} 2$, marzo de 1967, off-set. $22 ’ 5$ x 17’ 5 cm, Milán.

${ }^{22}$ Lorraine WILD, “Agency and urgency: the medium and its message”, en A. Blauvet (ed.), Hippie modernism: the struggle for utopia, Minneapolis, Walker Art Center, 2017, p. 46.

23 A continuación ofrecemos la traducción de algunos de ellos: "Decline and Fall of Hippieland” ("Decadencia y caída de 'La Tierra Hippie"”), "Mayor Warns Hippies to Stay Out of Town" ("El alcalde advierte a los hippies de que se vayan de la ciudad"), "Warning On Hordes of Hippies" ("Precaución hacia las hordas de hippies") , "City Toning Down its "war' on hippies" ( "La ciudad refuerza su 'guerra' contra los hippies"). 


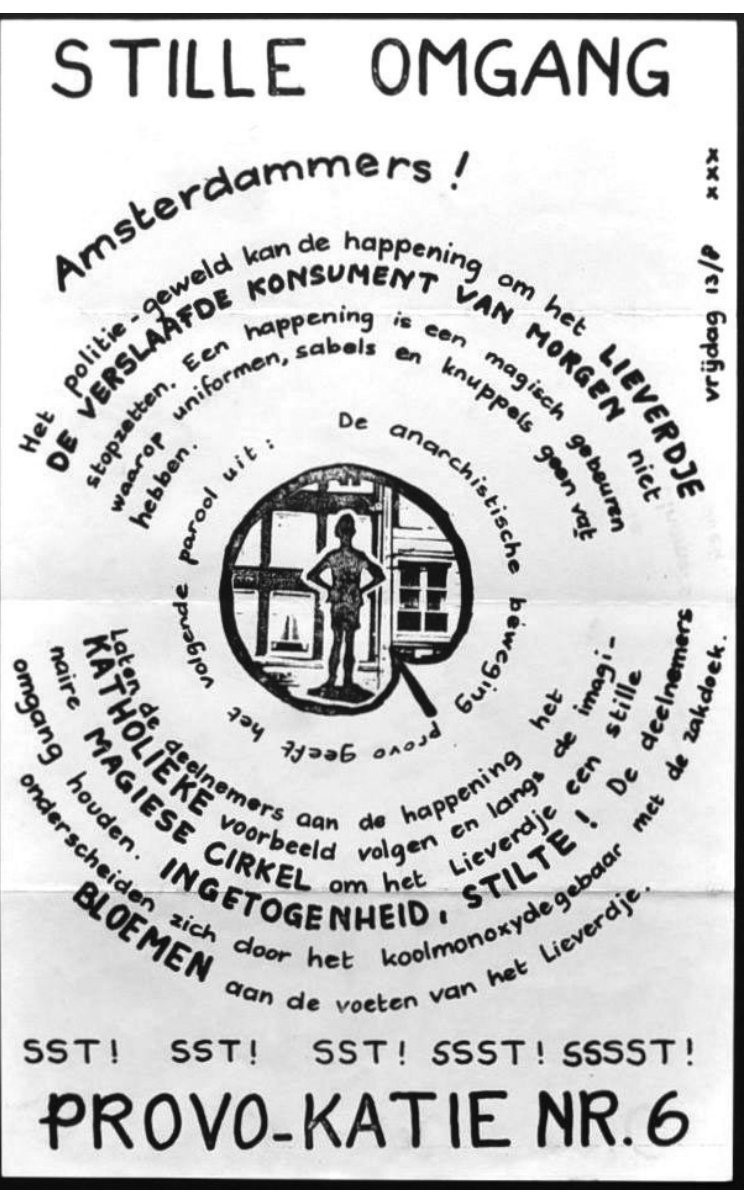

Fig. 5. Movimiento provo, Provokatie $\mathrm{n}^{0}$ 6, "Stille imgang" ("Procesión silenciosa"), 13 de agosto de 1965, mimeografía, 21’5 x 34 cm, Ámsterdam. toria por todo el espacio de la página ${ }^{23}$. De esta forma, la portada se revelaba como una superficie cacofónica, saturada de palabras, exclamaciones y acusaciones agresivas que apenas dejaban resquicios para la reflexión o el diálogo, reproduciendo en su propio diseño las lógicas verticales y autoritarias que modelaban la prensa convencional. Al mismo tiempo, en contraste con el ruido tipográfico, el titular del Berkeley aparecía tímidamente, conjugando un verbo en jerga, políticamente incorrecto, con la manualidad caligráfica, con el fin de proponer un interrogante que desencadenara la reflexión colectiva. Emergía así el "amateurismo" celebrado coetáneamente por Marshall McLuhan, pionero teórico de los medios:

El profesionalismo sumerge al individuo en los patrones del ambiente total. El amateurismo busca el desarrollo de la conciencia total del individuo y la conciencia crítica de las reglas básicas de la sociedad. El aficionado puede darse el lujo de perder. El profesional tiende a clasificar y especializarse, a aceptar acríticamente las reglas básicas del entorno ${ }^{24}$.

McLuhan incidía, de esta forma, en la productividad de la práctica amateur en un momento de intensa profesionalización y depuración del diseño gráfico en los Estados Unidos, al calor de las transformaciones económicas acontecidas en la década de los 60. Estas eran consideraciones que encontraremos, si bien en años posteriores, en los proyectos editoriales marginales desarrollados en la ciudad de Madrid. Como declaraba Enrique Pardo, miembro de los Laboratorios Colectivos Chueca (La Cochu), efímera distribuidora de prensa marginal en la ciudad, la oposición crítica hacia lo que irónicamente denominaba el complejo "Televisión-Prensa-Publicidad-Radio-Siéntese usted bien, relájese y descanse-en realidad nada tiene la menor importancia" cruzará las reflexiones de la prensa marginal, no solo pensada como una herramienta para la disidencia civil, sino como un dispositivo que alentaba la desalienación de las subjetividades, puesto que "usando los mismos medios, hay gente que intenta comunicar experiencias absolutamente opuestas, [...] y derribar todas las taras de una prensa mediatizada por el poder" 25 . En el contexto madrileño, la prensa marginal parte de unas premisas políticas doblemente emancipadoras: por un lado, respecto al régimen franquista, en vías de descomposición; por el otro, respecto a las restricciones del capitalismo industrial fordista (fig. 8). El interés histórico de estas producciones reside, por tanto, en su testimonio liminal, en tanto que índice visual de estrategias de transgresión y resistencia, de modos de vida y subjetividades que se querían disidentes.

En 1975 surgían Bazofia y Catacumba, las primeras publicaciones sin depósito legal aparecidas en E1 Rastro madrileño, a las que vinieron a sumarse una miríada diversa y rica de pequeños fanzines, guías y

\footnotetext{
24 Marshall McLuhan et al., The medium is the massage, Londres, Penguin Books, 1971, p. 93.

25 Enrique PARDO, "Réquiem por la prensa convencional", Ajoblanco Extra "Prensa Marginal” (octubre de 1978), p. 9.
} 
revistas que experimentaron su mayor crecimiento entre 1977 y 1978, época en la que nacen las primeras coordinadoras comunitarias de producción y distribución de prensa marginal: la Premamá y, posteriormente, La Cochu. Estas producciones surgen como contestación a la creciente centralidad de la prensa comercial, desencadenada por la intensificación de la liberalización del mercado cultural en el Estado español, canalizador del discurso reformista de la Transición a través de medios como El País, Cambio 16 o $A B C^{26}$. Aquella prensa operaba en un régimen de semi-clandestinidad que le permitía prescindir de los canales oficiales de producción y distribución. Producida con enormes dificultades económicas, se daba a conocer en entornos muy localizados como El Rastro, la Plaza Dos de Mayo, los puestos de la Cuesta de Moyano o el Ateneo Politécnico de Prosperidad. Independientemente del acabado final, estas publicaciones se revelaban como una acción en sí mismas, como señalaba J.M. Costa de manera coetánea:

No compramos una obra de arte, compramos el esfuerzo de parir una mierda [...] Y si algo es bello nos felicitamos porque es como un regalo que ni esperábamos ni exigíamos ${ }^{27}$.

Costa indicaba de esta forma las implicaciones afectivas, políticas y simbólicas que eran movilizadas en el acto de consumo de estas publicaciones baratas,

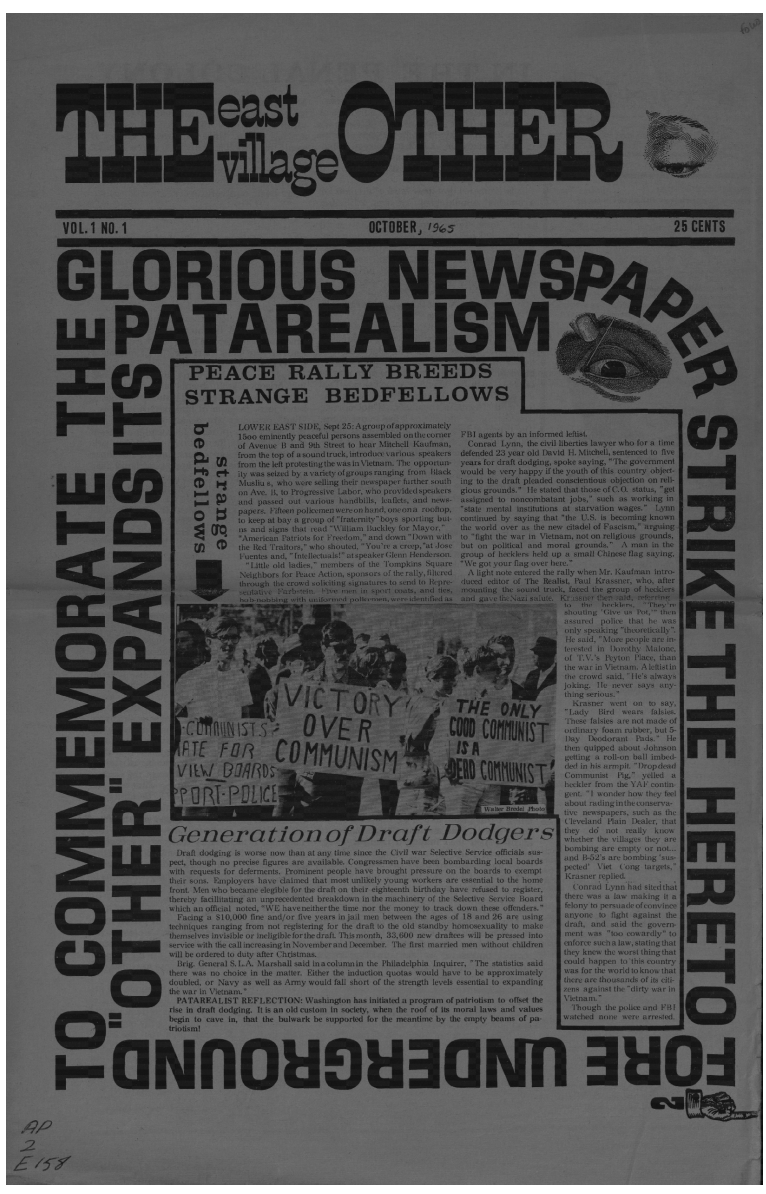

Fig. 6. Portada de The East Village Other vol. $1 \mathrm{n}^{\mathrm{o}} 1$, Nueva York, octubre de 1965. amateurs, donde el producto final era desplazado para poner en valor los modos de vida que le habían dado lugar. Se trataba de una renuncia explícita al fetichismo del objeto, de un desprecio premeditado por el producto resultante que venía a incidir, ante todo, en su proceso de producción, el "parto", en tanto que alumbramiento de un objeto que se quería puro, precivilizado, anterior a las normas y a las estructuras de poder.

\section{Antifranquismo, mass media y sociedad de consumo}

A continuación trataremos de trazar una panorámica que recoja las experiencias comunicativas desarrolladas en el seno del antifranquismo estudiantil de finales de la década de los 60, con el fin de localizar históricamente las discusiones sobre los mass media en la España tardofranquista y transicional, y afinar la comprensión de fenómeno de la prensa marginal madrileña del que aquí nos ocupamos.

${ }^{26}$ Dos trabajos fundamentales para profundizar en el papel que desempeñó la prensa en la Transición española son Gerard ImBert et al., El País o la referencia dominante, París, Centre National de la Recherche Scientifique, 1988; Ignacio FonTES y M.A. Menéndez, El parlamento de papel: las revistas españolas en la transición democrática, Madrid, Asociación de la Prensa de Madrid, 2004.

27 Costa, 1978, p. 3. 


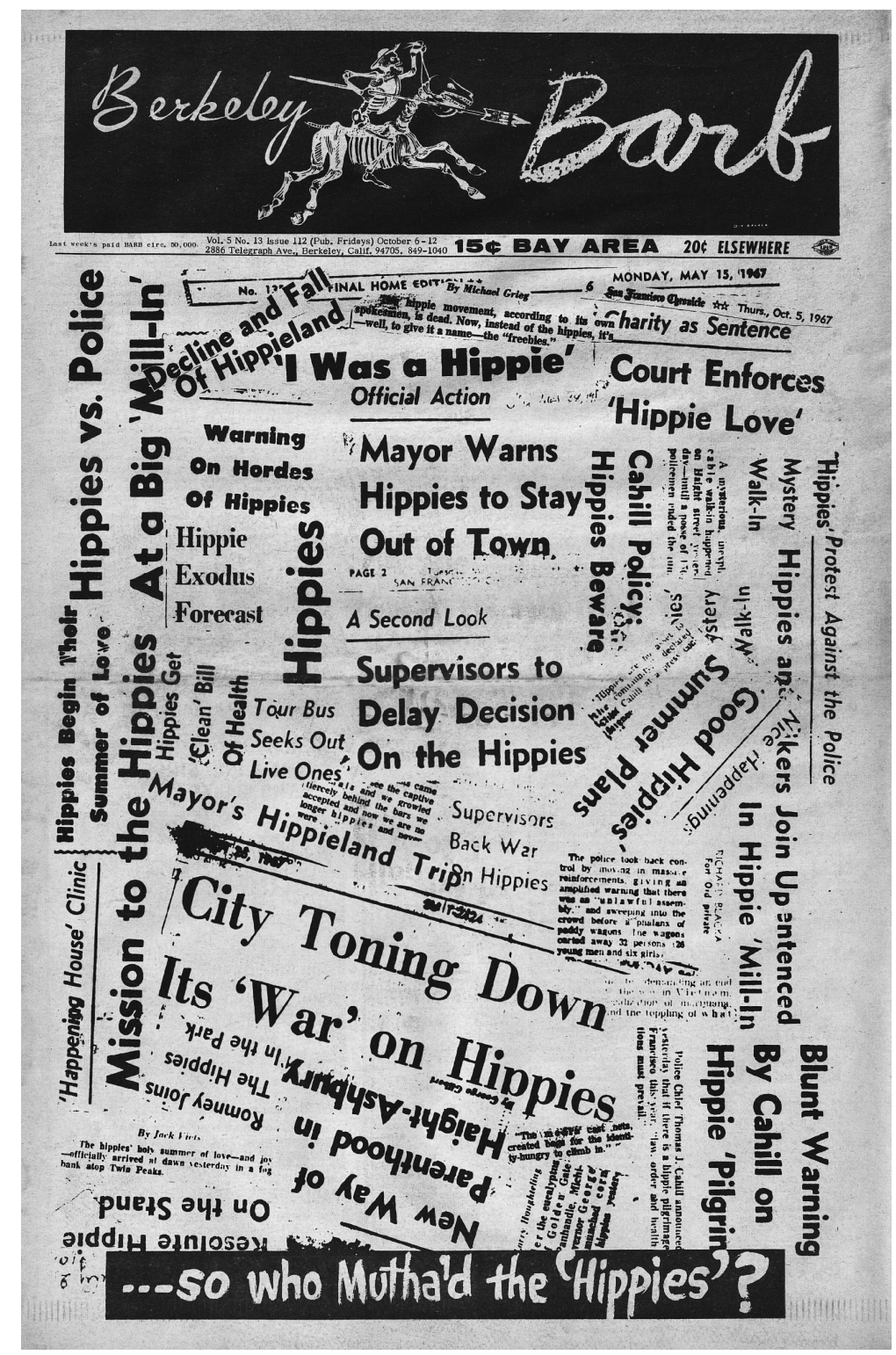

Fig. 7. Portada de The Berkeley Barb vol. 5. nº 13, Berkeley, octubre de 1967.

El debate sobre los medios de comunicación de masas se traduce, en el contexto situado de la España tardofranquista y transicional, en una amplia experimentación y diálogo con las movilizaciones sociales. Durante las revueltas estudiantiles de 1965 en la Universidad de Madrid, los periódicos del régimen $-A B C$ y Alcázar, principalmente- fueron quemados frente a las puertas de las facultades de Filosofía y Ciencias Políticas, "en una especie de acto tribal de exorcización y purificación"28. En la universidad española surgirán iniciativas editoriales autónomas que sientan precedente, como es el caso de Gaceta Universitaria, una revista llevada a cabo por y para universitarios, fundada en Pamplona en el año 1962 y que años más tarde se trasladará a Madrid; o la revista mural El Tigre, creada en la Universidad de Sevilla en 1968. También se experimentará con otros medios comunicativos: en la siguiente década, aparecen en distintas

\footnotetext{
28 ORDOVÁs, 1977, p. 27.
} 


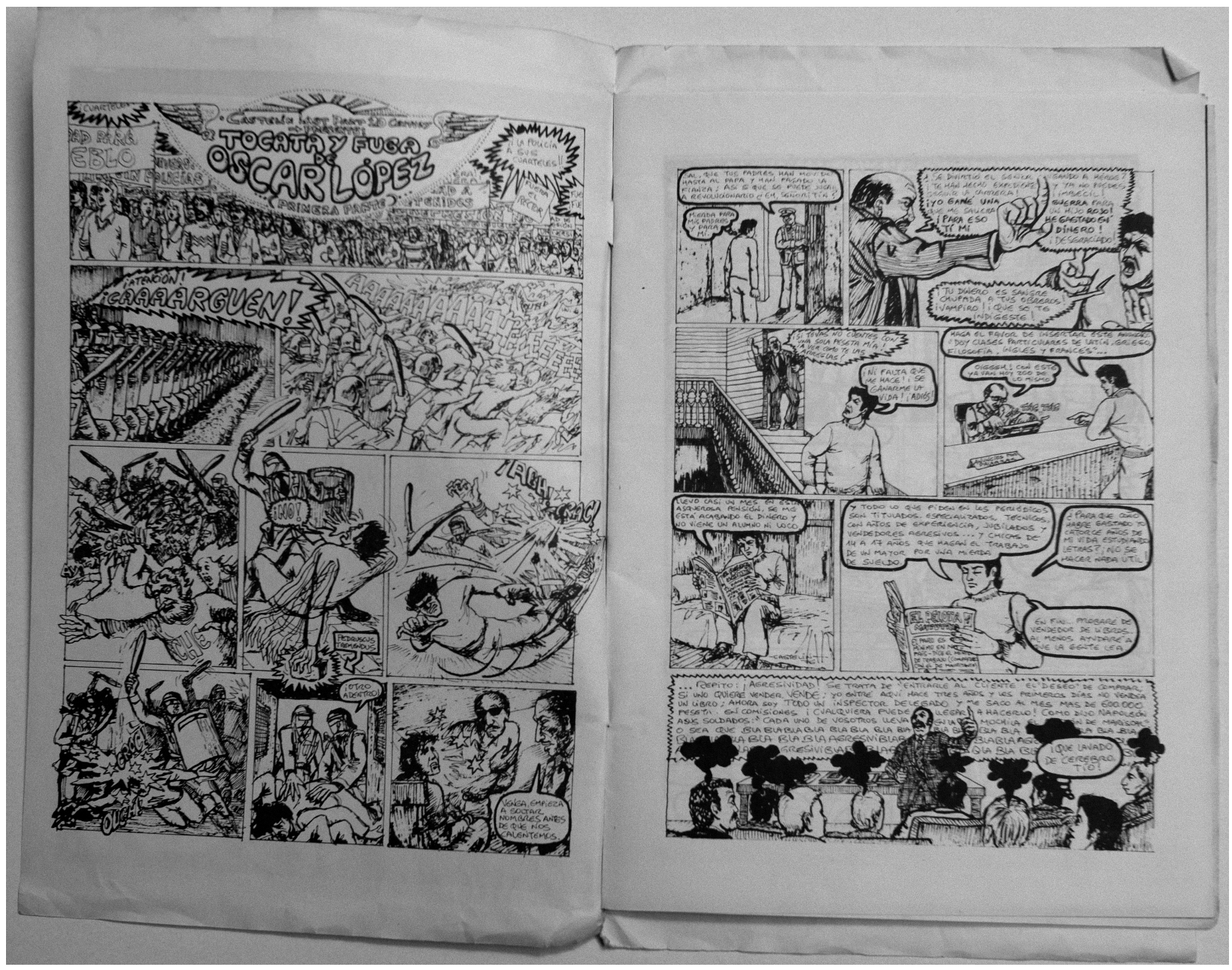

Fig. 8. Castelín, “Tocata y fuga de Óscar López”, Bazofia nº 5, 1976 archivo personal de Alberto García-Alix.

partes del Estado iniciativas que buscan apoyar y expandir las luchas al terreno mediático. En el campo del vídeo y el cine comunitario encontramos experiencias como la del Colectivo de Cine de Madrid, fundado en 1975 por un grupo de estudiantes, que filma varias películas en las que documentan y retratan distintas acciones desde los frentes de lucha y oposición o el caso de Vídeo-Nou / Servei de Vídeo Comunitario, que surge en 1977 con el fin de apoyar el tejido asociativo de base bajo el concepto de "animación cultural", nutriéndose de experiencias previas desarrolladas en Francia, Quebec y Bélgica ${ }^{29}$. Al final de la década también despuntarán las radios libres, entre las que destaca la célebre Ona Lliure catalana (1979), cuyo objetivo "prioritario y global" era "dar la palabra a la GENTE, con mayúscula. Es decir, a todas aquellas personas que no tienen en la vida la oportunidad de expresarse a través de un medio para comunicarse, en el verdadero sentido, con el resto ${ }^{30}$ ". Estas iniciativas dialogan con la experiencia desarrollada por la prensa antiautoritaria, donde se ensayan otras narrativas, otras maneras de construir la comunicación, otros circuitos de producción y distribución de la información.

29 “Dossier Video-Nou: 1977-1978”, Centro de Documentación del Museo Nacional Reina Sofía, Archivo Video-Nou, n42.

30 Jesús CARrILlo et al., "Medios libres: Ona Lliure y RTV Cardedeu (1979)...»", en Desacuerdos. Sobre arte, políticas y esfera pública en el Estado español, vol.3, Centro José Guerrero-Diputación de Granada, Museu d'Art Contemporani de Barcelona, Museo Nacional Centro de Arte Reina Sofía y UNIA arteypensamiento, 2009, vol. 5, pp. 177. 
En el análisis que aquí presentamos tomaremos como punto de partida los debates en torno al lenguaje de la historieta desarrollados por la Célula de Pintores del $\mathrm{PCE}^{31}$, probablemente el género impreso más popular en la década de los $60^{32}$, con el fin de comprender la importancia que se da al cómic y la ilustración en la prensa marginal madrileña. A finales de 1969, la Comisión Función del Arte en la Sociedad comenzó a reunirse en la Galería Redor ${ }^{33}$ con el objetivo reflexionar sobre el papel de los medios de comunicación de masas en las sociedades de consumo. La Comisión había nacido en el seno de la Célula de Pintores del PCE con la vocación de generar un tejido reflexivo que restaurara los vínculos de la producción artística con la sociedad que la albergaba y rompiera la alienación secular del arte junto a los intereses de la burguesía.

En una de aquellas sesiones, celebrada el 29 de diciembre de 1969, se discutió acerca de “[...] la validez del cuadro de caballete [...] y la necesidad de otros medios de expresión tales como un nuevo tipo de 'cómic' o cualquier otro de los actuales medios de la cultura de masas, para llegar a una [...] difusión masiva del Arte ${ }^{34}$ ". En el acta de la reunión se recogen las distintas intervenciones de los participantes, que coinciden en mirar el "cuadro de caballete" como un icono del proceso de cercamiento al que la clase burguesa había sometido al arte y la creatividad popular, privatizando de esta forma la experiencia estética. Al mismo tiempo, también se señalaba a los medios de comunicación como "canalizaciones populares del anhelo colectivo", y se incidía en la necesidad de aplicar estos nuevos lenguajes a la creación artística que se quería comprometida con su tiempo. Finalmente, la Comisión acordaba continuar reflexionando sobre el lenguaje del cómic, tomando como punto de partida el trabajo de dos de sus miembros, los pintores y dibujantes José Orcajo y Reimundo Patiño.

A partir de las reuniones organizadas por la Comisión Función del Arte en la Sociedad, los miembros de Redor dedicaron varios proyectos al lenguaje de la historieta, como la exposición "35 años de tebeos en España” (1973), que analizaba teórica, artística y estéticamente el cómic español de postguerra; o el trabajo inconcluso titulado "El Cómic Antiimperialista", que Patiño realizó entre 1972 y 1973 junto a Tino Calabuig y Francisco Escalada. En 1973, Patiño también presentaba en Redor O home que falaba vegliota, un cómic-mural en lengua gallega en el que podemos encontrar los fermentos narrativos y visuales que comenzarían a subvertir los códigos establecidos por la historieta comercial. Tal y como se señala en el texto que acompañaba a la muestra, los integrantes de Redor buscaban con ella iluminar el potencial estético-político del cómic:

Si recurrimos en ayuda del arte "culto", ¿qué batalla puede ofrecer en cuanto a inmediatez y eficacia de difusión de mensajes colectivos? [...] ¿Y por qué no transmutar los medios enajenantes en liberadores? El arte popular no ha muerto, lo que ha hecho es variar cauces y manifestaciones. Uno de ellos el "cómic". El "cómic" es uno de dichos cauces. Quizás el más importante ${ }^{35}$.

La transmutación de los medios enajenantes, o la liberación de los mismos, se convertía así en la tarea del artista-militante que buscaban encumbrar los entornos de Redor. Las viñetas, convertidas en grandes serigrafías diseminadas por la pared, lograban quebrar los cercamientos de la experiencia individual, colec-

31 Fundada en 1968 por Tino Calabuig, Alberto Corazón y Valeriano Bozal, la Célula nace con el objetivo de establecer una alianza que participara en el establecimiento del socialismo tras la inminente caída de la dictadura. Véase Juan AlBARRÁN, "Lo profesional es político: trabajo artístico, movimientos sociales y militancia política en el último franquismo", Espacio, tiempo y forma, 3-VII (2015), p. 250.

32 Juan Antonio Ramírez, La historieta cómica de postguerra, Madrid, Cuadernos para el Diálogo, 1975, p. 23.

${ }^{33}$ La galería-taller Redor (1969-1974) fue fundada en Madrid por Tino Calabuig y Alberto Corazón con el objetivo de abrir un taller dedicado a la obra gráfica, que después ampliará sus funciones a las de sala de exposiciones. Más tarde se incorporarán a la Galería los artistas Francisco Escalada, Reimundo Patiño y algunos estudiantes de la facultad de Bellas Artes como Miguel Gómez.

34 “Acta de la $11^{\mathrm{a}}$ reunión de la Comisión Función del Arte en la Sociedad", Centro de Documentación del Museo Nacional Reina Sofía, Archivo Redor-Calabuig. Sección Asociación de Artistas Plásticos, nº 60.

35 "Texto de sala de la exposición 'O home que falaba vegliota"”, Centro de Documentación del Museo Nacional Reina Sofía, Archivo Redor-Calabuig, Sección Redor, nº 28. 
tivizando el espacio de la mirada. Lejos de asimilar el formato mural, empleado por Patiño, a las grandes pinturas de caballete, este se podría relacionar asimismo con los célebres periódicos-murales que habían aparecido en el seno del movimiento estudiantil español, revelándose por tanto como un medio de comunicación plenamente integrado en la visualidad militante de la época.

En $O$ home que falaba vegliota se narra la historia de uno de los últimos hablantes de "vegliota", perseguido por los representantes de todas las grandes naciones del mundo en el transcurso de una suerte de Olimpiadas imperialistas en las que se disputan el honroso título de "Mayor Asesino del Mundo" (fig. 9). La referencia al vegliota, lengua románica

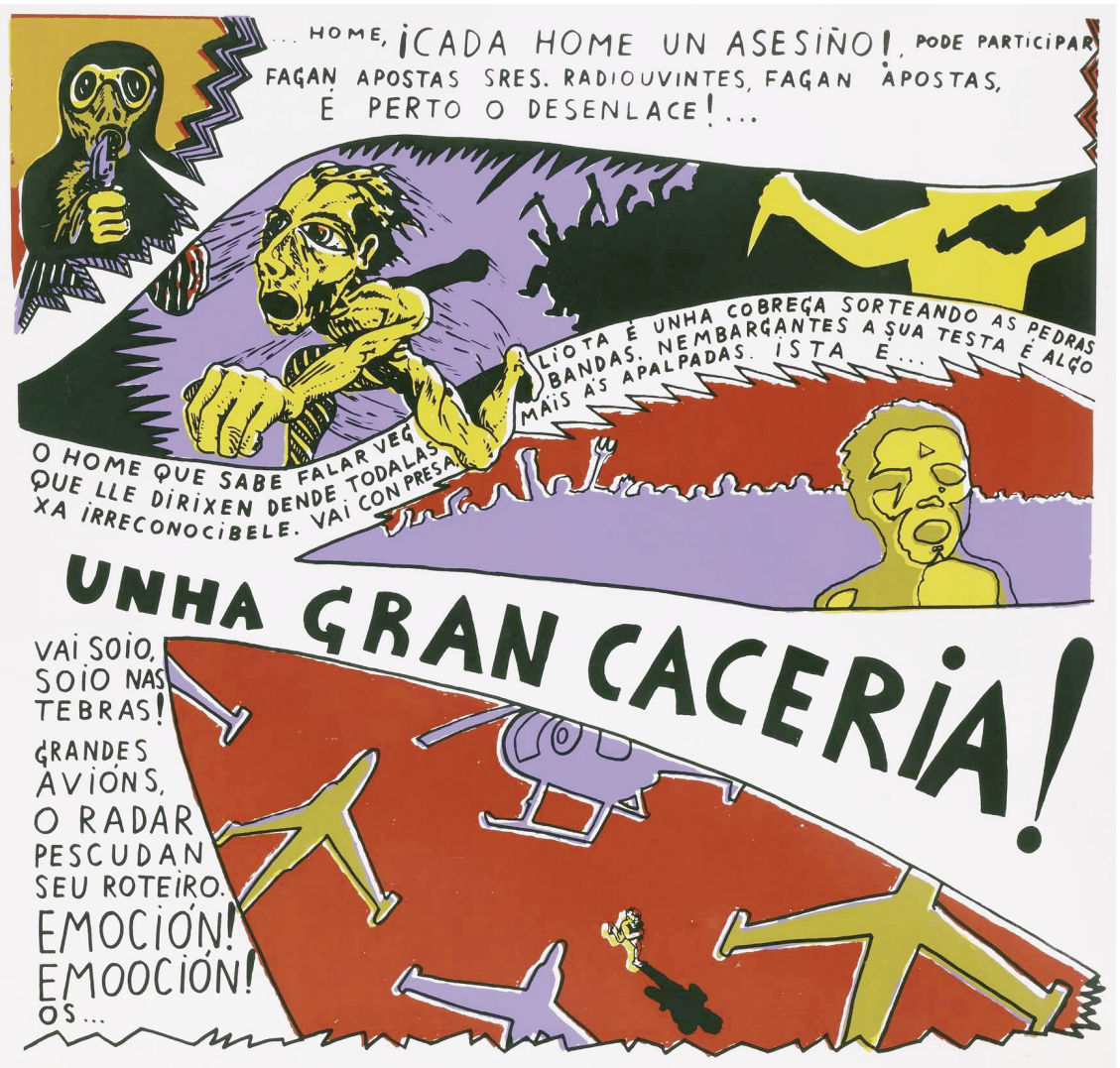

Fig. 9. Reimundo Patiño, O home que falaba vegliota, 1972, serigrafía, 110 x 110 $\mathrm{cm}$, Madrid, MNCARS [AD06399].

extinta hablada en la región austriaca de Dalmacia, le permite a Patiño visibilizar la problemática gallega en el marco del último franquismo y, en última instancia, denunciar la violenta represión sufrida por las minorías étnico-lingüísticas. Frente a la caricaturización cómica de las culturas periféricas que coexistían en el Estado español, plasmada en figuras como la de Josechu El Vasco, el personaje desarrollado por Joaquín Muntañola para TBO que retrataba la vida costumbrista y estereotipada del hombre vasco (fig. 10), el cómic de Patiño venía a incidir en la represión y el dolor, gráfica y narrativamente, infringido por el nacionalismo franquista.

De forma coetánea, encontramos imágenes que invierten radicalmente las representaciones de los héroes del cómic comercial, como es el caso de "Fantasy, el azote del héroe", una suerte de antípoda irreverente de El Guerrero del Antifaz o El Capitán Trueno, que aparece en Bang! Fanzine de los tebeos españoles ${ }^{36}$, en la primavera de 1970. Definido por su creador, Ignacio Fontes de Garnica, como un personaje de "anti-cómic", el endeble y mezquino Fantasy tenía la vocación de encarnar la maldad inherente al ser humano, negada y reprimida en las historietas comerciales. Garnica ensaya varias representaciones de Fantasy, con un dibujo torpe y tosco, en las que se muestra al anti-héroe protagonizando distintos episodios de dudosa moral, entre las que destacan un conjunto de viñetas cuyo diseño asimila la forma de un muro de piedra seca (fig. 11). En ellas,

36 La publicación Bang! Fanzine de los tebeos españoles fue fundada en Madrid, en 1968, por Antonio Lara y Antonio Martín. La publicación se preocupó desde sus inicios por la generación de un tejido teórico sólido en torno al lenguaje de la historieta. Vinculada al G.E.L.P.I. (Grupo de Estudio de las Literaturas Populares y de la Imagen), en ella se desarrolla una elaboración intelectual y visual que posibilita la germinación de una cultura crítica del cómic, históricamente marginado y relegado al terreno del consumo infantil o juvenil. 


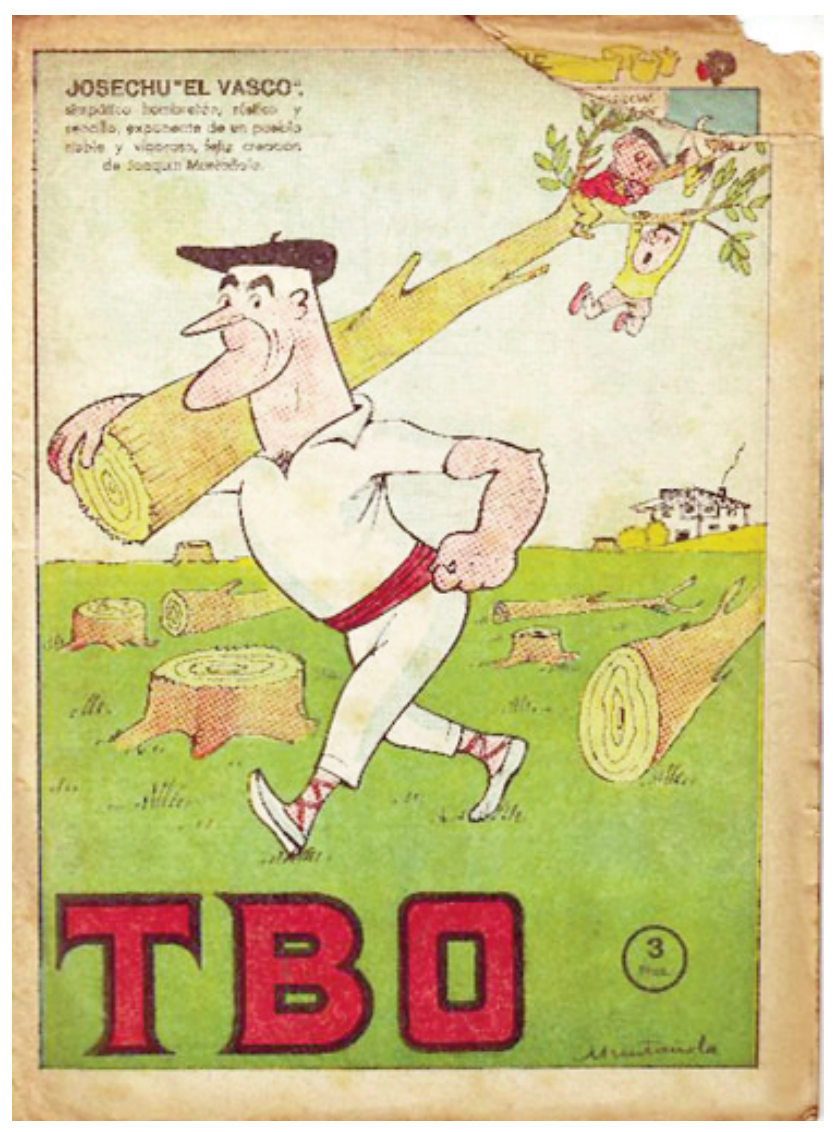

Fig. 10. Joaquín Muntañola Puig, “Josechu 'El Vasco'”, TBO, Barcelona, 31 de enero de 1964.
Fantasy persigue a mujeres, amenaza a inocentes gatos o atenta contra imponentes catedrales. Como ocurría en el cómic-mural de Patiño, Fantasy emerge como una figura escuálida y frágil, regocijándose en la representación de corporalidades alternativas que desbordaban la normatividad del héroe del cómic comercial. Sin embargo, el personaje de Fantasy profundiza en la estrategia de la irreverencia, desechando toda gravedad o solemnidad en su crítica visual, lo que preludia las estrategias de subversión simbólica y visual del cómix setentero.

En las páginas de Bang! y sus suplementos pueden ser rastreadas problemáticas e imaginarios latentes, posteriormente explorados por la prensa marginal en la década posterior. Es recurrente, en este sentido, la figura del "dibujante alienado", que aparece retratada en la historieta "Love Strip", firmada por Luis García y Víctor Mora, que es acompañada por un análisis teórico sobre la situación de la industria y unas breves reflexiones acerca de las posibilidades de agencia de los dibujantes profesionales. En "Love Strip", elaborada únicamente con una expresiva tinta negra, se relata la crisis existencial de Carlos, un dibujante que trabaja para una gran editorial dedicada a la historieta, produciendo cómics románticos "para señoritas" ${ }^{\prime 37}$. El personaje se siente abrumado por el ritmo de trabajo monótono que le impone la edito-

rial, y a lo largo de las páginas se irá profundizando en las sensaciones de angustia y contradicción que lo acompañan cotidianamente. En la viñeta que aquí se presenta (fig. 12) se muestra al dibujante sentado en su mesa de trabajo, sosteniendo un árido monólogo interior mientras elabora una de esas historietas "rosas" hasta que alza la voz con desesperación, lanzando los utensilios por los aires. Cabe destacar, en este sentido, algunos de los recursos visuales empleados en la imagen, como la utilización de un elevado pictoricismo en las representaciones del "mundo real", que densifican las sombras de los cuerpos, los espacios y los objetos, en contraste con la higienización de la viñeta que se encuentra realizando el dibujante.

\section{Políticas y poéticas del carajillo}

Las experimentaciones visuales en el terreno de la historieta permiten explicar, en gran medida, la gran relevancia que se dará al cómic en la prensa contracultural ${ }^{38}$. Nos queremos detener, en este punto, en las cris-

\footnotetext{
37 Sobre la problemática del cómic femenino y su intersección con el feminismo en la época véase Katia ALMERINI, "La irrupción del feminismo en el cómic español de los setenta", Anuario del Departamento de Historia y Teoría del Arte UAM, vol. 27 (2015), pp. 213-229, http://dx.doi.org/10.15366/anuario2015.009. En su artículo, Almerini retoma el texto clásico de Juan Antonio Ramírez, El cómic femenino en España. Arte sub y anulación (1975), para explorar los trabajos de dibujantes como Montse Clavé o Nuria Pompeia.

${ }_{38}$ Un amplio estudio sobre el cómix underground en España lo podemos encontrar en la publicación de Pablo DopICO, El cómic underground español, 1970-1980, Madrid, Cátedra, 2005.
} 
talizaciones de la imaginación política vertidas en la prensa marginal madrileña, híbrido de subversión contracultural y casticismo, a partir del análisis de la portada del Carajillo (1975) ${ }^{39}$, una de las primeras ediciones marginales aparecidas en la ciudad, que recogía distintas historietas de dibujantes amateurs (fig. 13).

Frente al imperio tecnocrático del rendimiento, la optimización y la mercancía, el café carajillo se mostraba irreverente, ridículamente antagonista, castizamente subversivo. Icono de temporalidades y modos de vida en extinción -el modo chulapo, madrileño y proletario-, el carajillo se vinculaba a rituales populares de socialización liberados de las exigencias productivas del capital. La tipografía manual que rotulaba el primer Carajillo emulaba al característico logo de Coca Cola -como ya hiciera el primer Ajoblanco en 1974-, y daba forma a una contradictoria ironía: el carajillo, en su inutilidad, en su esterilidad frente al mundo del trabajo y el mercado, aparecía enunciado con letras publicitarias anidadas en las retinas urbanas, la barroca tipografía que daba forma al símbolo indiscutible de la american way of life. Junto al rótulo, encontramos representada una taza de café humeante, carente de toda perspectiva, ingenuamente deforme, que contrasta con la habilidad con la que es plasmada la figura de un acordeonista. Un acordeonista lumpen, indigente, desvestido de su prótesis pero elegantemente ataviado que, en su picaresca o atrofia social, emplea su fuerza de trabajo junto a la boca de metro de Plaza España (¿?), esperando algunas monedas.

Las políticas y poéticas del carajillo - parafraseando el texto de Peter Stallybrass y Allan White ${ }^{40}$, que aquí presentamos como un repertorio de imágenes, lenguajes y prácticas ligadas al universo simbólico de la icónica bebida, venían a solapar el amateurismo antiautoritario de la prensa sesentayochista con el casticismo madrileño, arrojando luz sobre la especificidad del contexto capitalino. Esta es también una poética de la improductividad y la pereza, enunciada desde un orgulloso pintoresquismo políticamente subversivo, asumida como traducción costumbrista del "ne travaillez jamais" situacionista. El Carajillo era la primera publicación alumbrada por el grupo Cascorro Factory, uno de los núcleos de prensa marginal pioneros en la capital, que había sido fundado por Alberto García-Alix y el dibujante Carlos Sánchez Pérez (Ceesepe $)^{41}$ ese mismo año. Cuando aparece el Carajillo, el grupo ya había establecido su sede en el puesto de venta que regentaban en El Rastro, así como en el piso del propio García-Alix, ubicado en la calle Encomienda, junto a la plaza del Cascorro ${ }^{42}$. La Cascorro Factory logró erigirse como una pieza clave en el desarrollo del movimiento madrileño de prensa marginal, en tanto que abre el espacio físico y simbólico que posibilita la aparición de circuitos, formatos y visualidades propias en el contradictorio contexto capitalino, si bien mantienen, al mismo tiempo, una estrecha relación con algunas de las publicaciones antiautoritarias barcelonesas más emblemáticas ${ }^{43}$.

En el trabajo desarrollado por la Cascorro Factory se cruzan las imágenes de la free press estadounidense con las poéticas castizas disidentes. A finales de 1976, el colectivo había comenzado a trabajar en una nueva publicación a la que titulan Comix Piratas, aludiendo a su doble acepción de irreverencia antinormativa y práctica de plagio, donde encontramos las historietas de emblemáticos dibujantes americanos como Robert Crumb, Moscoso o Rick Griffith traducidas al castellano. A partir de los cómix esta-

39 Carajillo (1975) fue editado por la Editorial Mandrágora y producido por el colectivo Cascorro Factory, incluyendo historietas de J.R.Ortega, Iñaki, Fernando Gálligo, Ceesepe y Santana. La revista nace con la voluntad de convertirse en una publicación periódica, aunque después de la persecución y el acoso sufrido por parte de las autoridades el proyecto será abandonado.

40 Peter Stallybrass, Allon White, "Política y poética de la transgresión”, en J., Carrillo, I. Estella (Eds.), Desacuerdos. Sobre arte, politicas y esfera pública en el Estado español, vol. 5, Centro José Guerrero-Diputación de Granada, Museu d'Art Contemporani de Barcelona, Museo Nacional Centro de Arte Reina Sofía y UNIA arteypensamiento, 2009, pp. 15-39.

41 Ceesepe, nombre artístico del dibujante Carlos Sánchez Pérez (1958, Madrid), había participado previamente en la breve experiencia del colectivo "El Capullo Verbenero", posteriormente escindido en los grupos que dieron forma a la revista Bazofia y el propio Carajillo.

${ }_{42}$ Alberto GARCíA-Alix, "Entrevista personal con la autora", marzo de 2018.

43 En 1974, un año antes de que apareciera el Carajillo, Ceesepe ya había comenzado a trabajar con la revista Star, manteniendo una fructífera colaboración a lo largo de toda la década; y en 1975 comienza a trabar amistad con la gente de El Rrollo, lo que inicia una serie de intercambios entre los grupos y consolida la participación del dibujante madrileño en el cómix Purita (1975). 


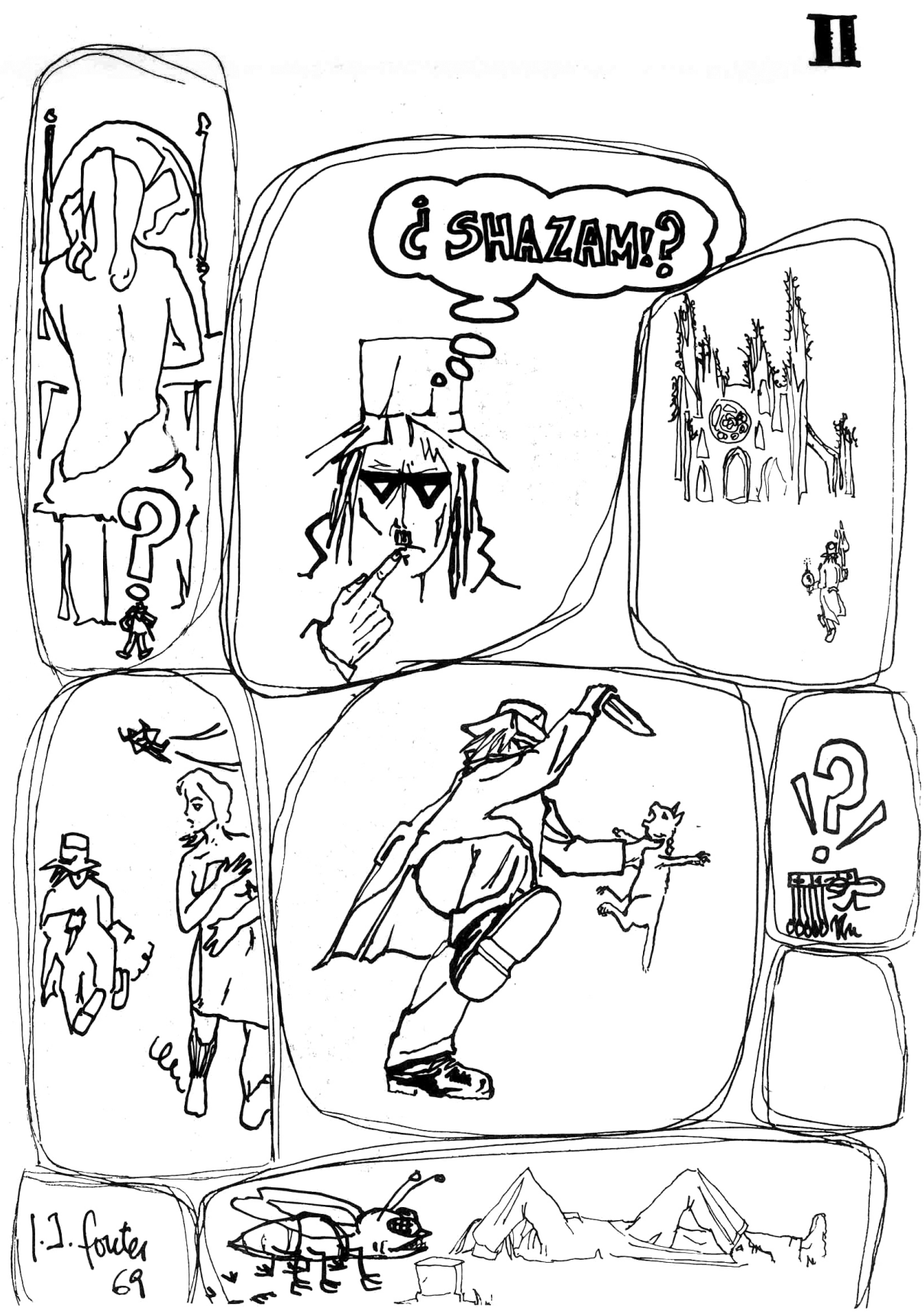

Fig. 11. Ignacio Fontes de Garnica, "Fantasy, el azote del héroe”, Bang! Boletín de urgencia, Madrid, abril de 1970.

dounidenses originales que conseguía Montxo Algora, amigo del grupo, los miembros de la Cascorro traducían los contenidos y reemplazaban manualmente los textos para después fotocopiarlos y venderlos en su puesto habitual ${ }^{44}$. Como ocurre con la mayoría de los proyectos desarrollados por la Cascorro, apenas lograron publicarse dos números de la serie en los que, sin embargo, podemos encontrar los índices visuales y poéticos que permiten enlazar las prácticas de la prensa marginal madrileña y la prensa underground americana.

44 García-Alix, 2018. 


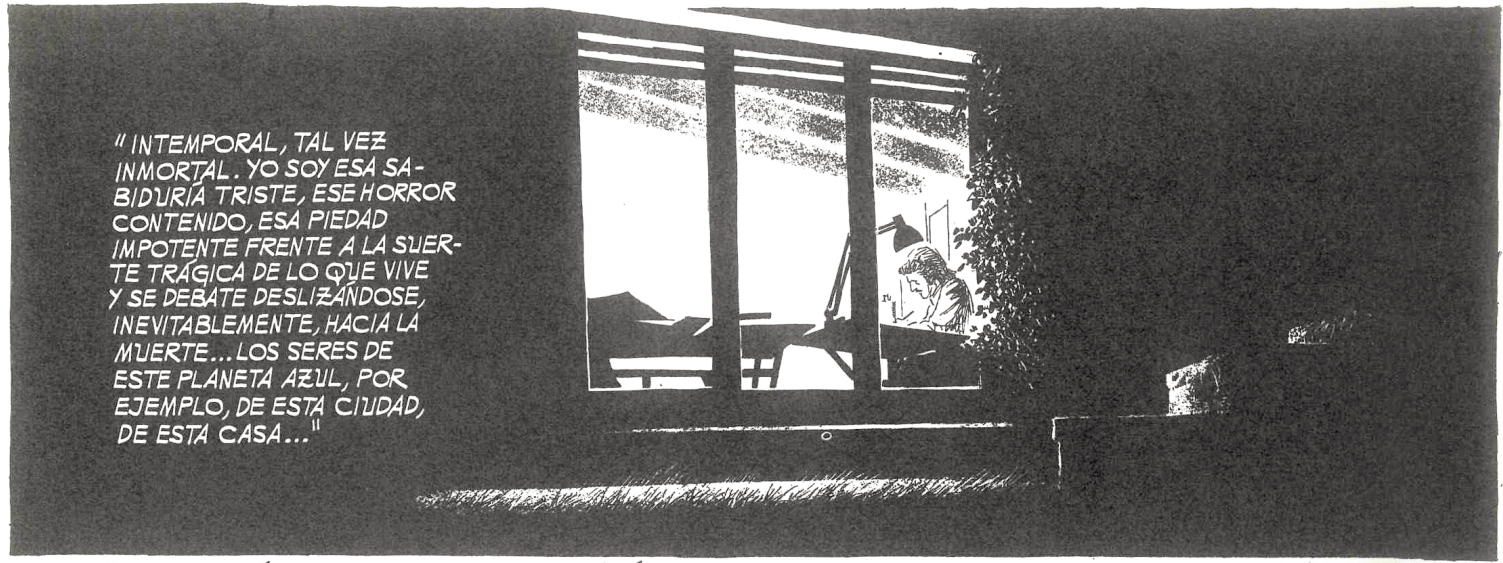

"Y, ¿POR QUÉ NO ESE HOMBRE...? VOY A SERÉL. QUIERO SER TESTIGO ATENTO Y PASIVO DE SU VIDA. VOY A SUFRIR, POR UN ESPACIO DE TIEMPO INDËTERMINADO, SU UUNICO DESTINO... YYA ESTA'! AHORA SOY EL, Y EL NUNCA LO SABRA."
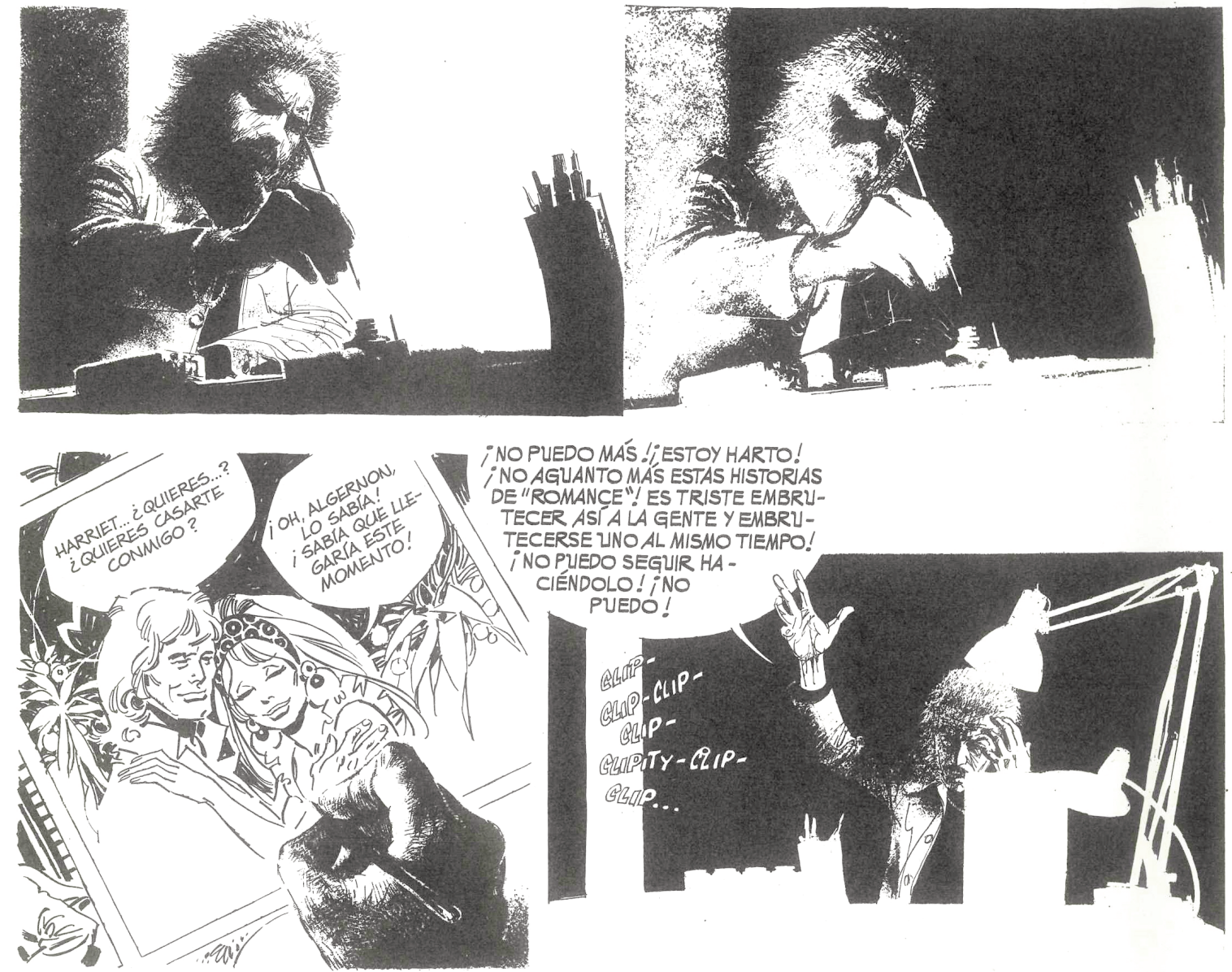

NO PUEDO MÁ́S ¿¿ESTOY HARTO!

DIO MAS ESTAS HISTORIAS

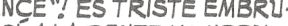
OPUEDO SEGUIR HAÉNDOLO! ¿NO PUEDO!

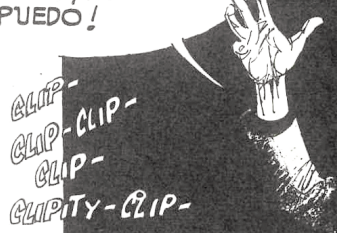
SBDS..
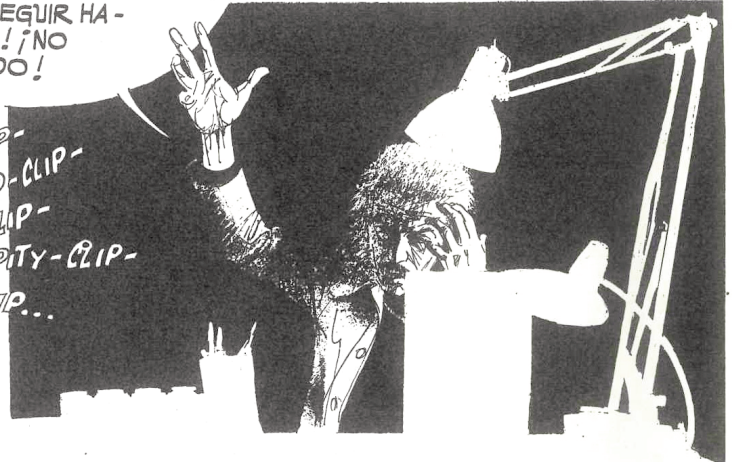

Fig. 12. Luis García y Víctor Mora, “Love Strip”, Bang! Información y estudios sobre la historieta n¹2, Madrid, 1975.

En ellos abundan las figuras masculinas irreverentes, ociosas y políticamente incorrectas como el célebre personaje creado por Bill Griffith, "Zippy, the pinhead", que podemos encontrar en el primer número, un anti-detective ataviado con un traje de payaso, de apariencia deforme y grotesca, cuya existencia se encuentra volcada al juego y al disfrute (fig. 14). Imbuido de una vitalidad infantil, Zippy se muestra como un anti-trabajador desvinculado de su identidad profesional, permanentemente deslumbrado por la densi- 


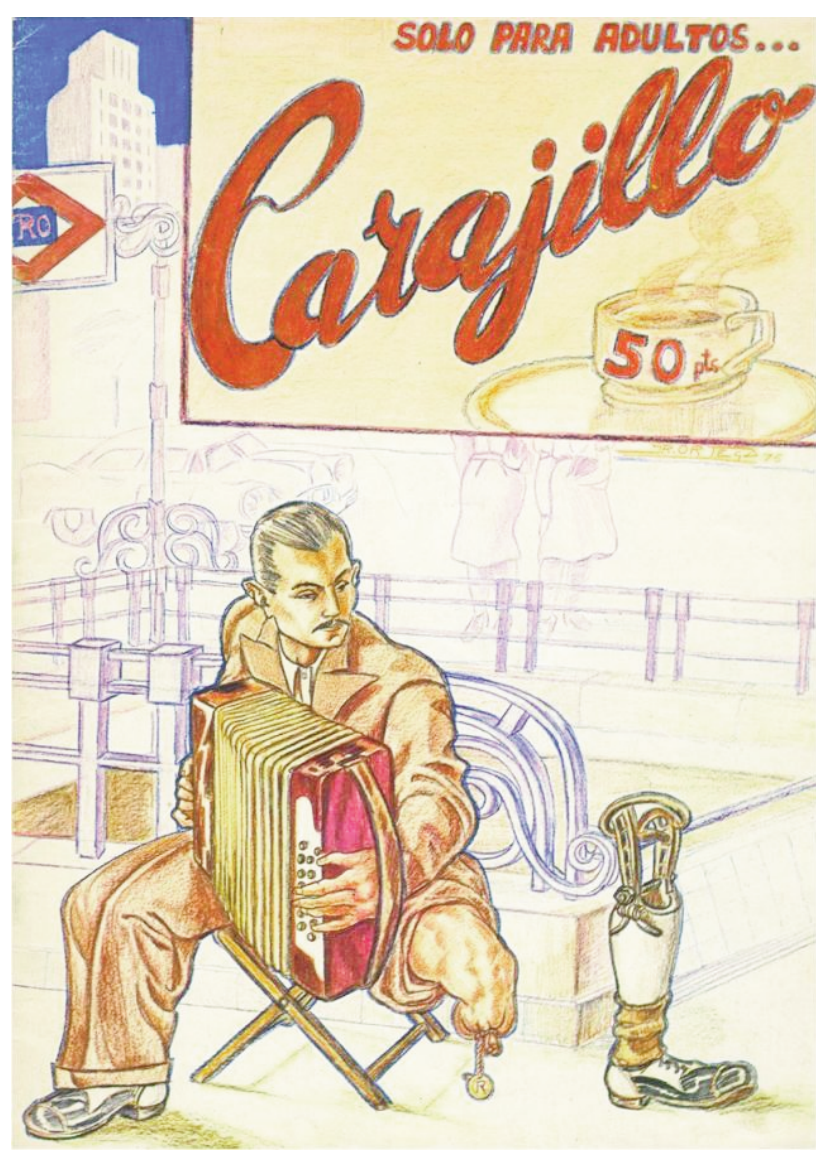

Fig. 13. J.R. Ortega, portada de Carajillo, Madrid, 1975, archivo personal de la autora. dad lúdica del mundo, lo que le hace distraerse constantemente de su labor. En las historietas de la free press vertidas en los apócrifos Comix Piratas, encontramos un rechazo latente a las instituciones disciplinarias como el trabajo asalariado o la familia, así como una celebración del hedonismo, de la subversión frente a las estructuras de control, imágenes que logran enhebrarse en las problemáticas situadas de la compleja ciudad de Madrid.

El café carajillo encarnaba, al mismo tiempo, una burla radical hacia la presión normativizadora que ejercía la sociedad tecnocrática tardofranquista. En el cómic Rata. Recuerdos del presente (1976), la gente de la Cascorro mostraba el crudo monólogo de un arquetípico patriarca del tardofranquismo tecnocrático a través de imágenes de gran sencillez, conformadas por viñetas horizontales en las que, homogéneamente, se mostraba la sobria figura junto al texto (fig. 15). El hombre, representado con rasgos difusos e impersonales, ojos huecos, ensombrecidos, describe las estrategias que planea seguir para disciplinar a su hijo ("[...] juro que mi hijo adorará a este Dios que me ha anulado, tengo métodos convincentes...") con el fin de que este "aprenda a odiar la vida como él mismo la odia”. El monólogo de Rata ponía imágenes, representaciones, al régimen policial que regía las familias en el franquismo, que amputaba de raíz auténticos mapas subjetivos a través de una metódica y estricta educación. La inquietante expresividad de la figura, esbozada a partir de leves cambios en la negrura de ojos y boca, era completada con algunos objetos significativos que iban apareciendo, a lo largo de las viñetas, en las manos de aquel padre: la cadena, la cruz, el periódico. En este caso, el periódico se presentaba como emblema de una alienación irrevocable ("hoy he leído algo sobre los últimos experimentos en USA sobre modificaciones del carácter [...]") que sostenía el régimen. La factura material de Rata, apenas tres páginas fotocopiadas y grapadas, es también llamativa, incidiendo al mismo tiempo en la necesidad de una rápida y barata difusión del material, la precariedad económica del que este emergía, así como el premeditado descuido del "resultado final", la "mierda" resultante a la que apelaba Costa en $1978^{45}$.

\section{Paisajes, lugares: geografías secretas en la prensa marginal madrileña}

Recopilar las imágenes de la prensa marginal posibilita, al mismo tiempo, proyectar un cuadro de geografías urbanas propias y distintas, impregnadas de significados: son las "geografías secretas" también referenciadas por Labrador ${ }^{46}$. La espacialidad marginal del Madrid postfranquista es tenue, silenciosa, y se encuentra atravesada por prácticas comunitarias radicalmente espontáneas que buscan romper, en última

\footnotetext{
45 Costa, 1978, p. 3.

46 A propósito del bar madrileño La Vaquería, dice Labrador: "es uno de los lugares emblemáticos de un amplio espacio de locales, centros culturales y garitos que construyen una geografía secreta en cada ciudad insular", en LABRADOR, 2017, p. 444.
} 


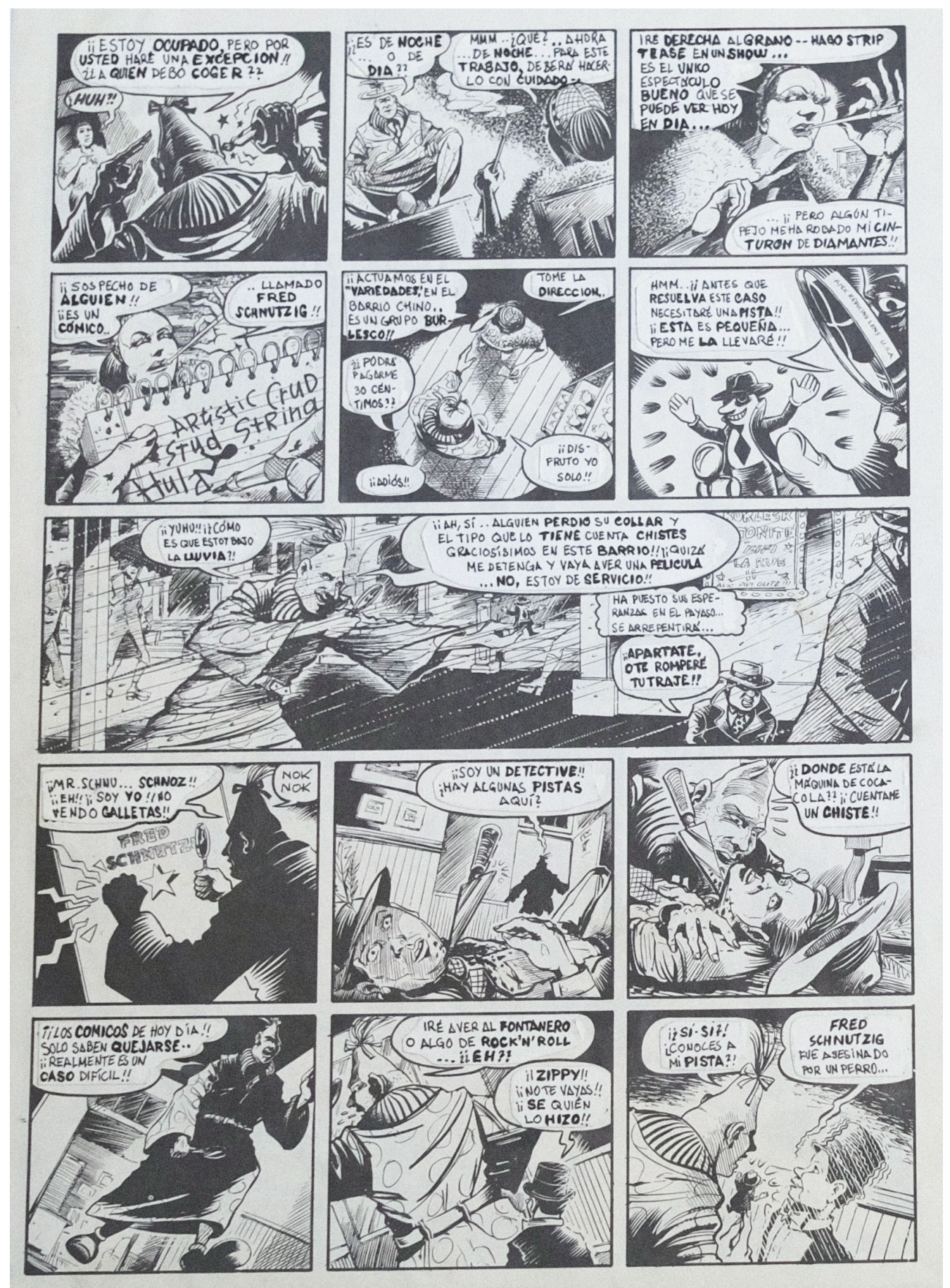

Fig. 14. Griffy, "Detective Zippy, el agente cabeza de chorlito", Comix piratas n 1, Madrid, 1977, Archivo personal de Alberto García-Alix.

instancia, los cercamientos tecnocráticos impuestos sobre los cuerpos. El Ateneo, El Rastro, los escasos bares "enrollados", las librerías de cómix o las tiendas de ropa se muestran en ella como un contrapunto perfectamente delimitado y resistente, construido colectivamente, que se opone de manera activa a la experiencia del espacio urbano franquista. 


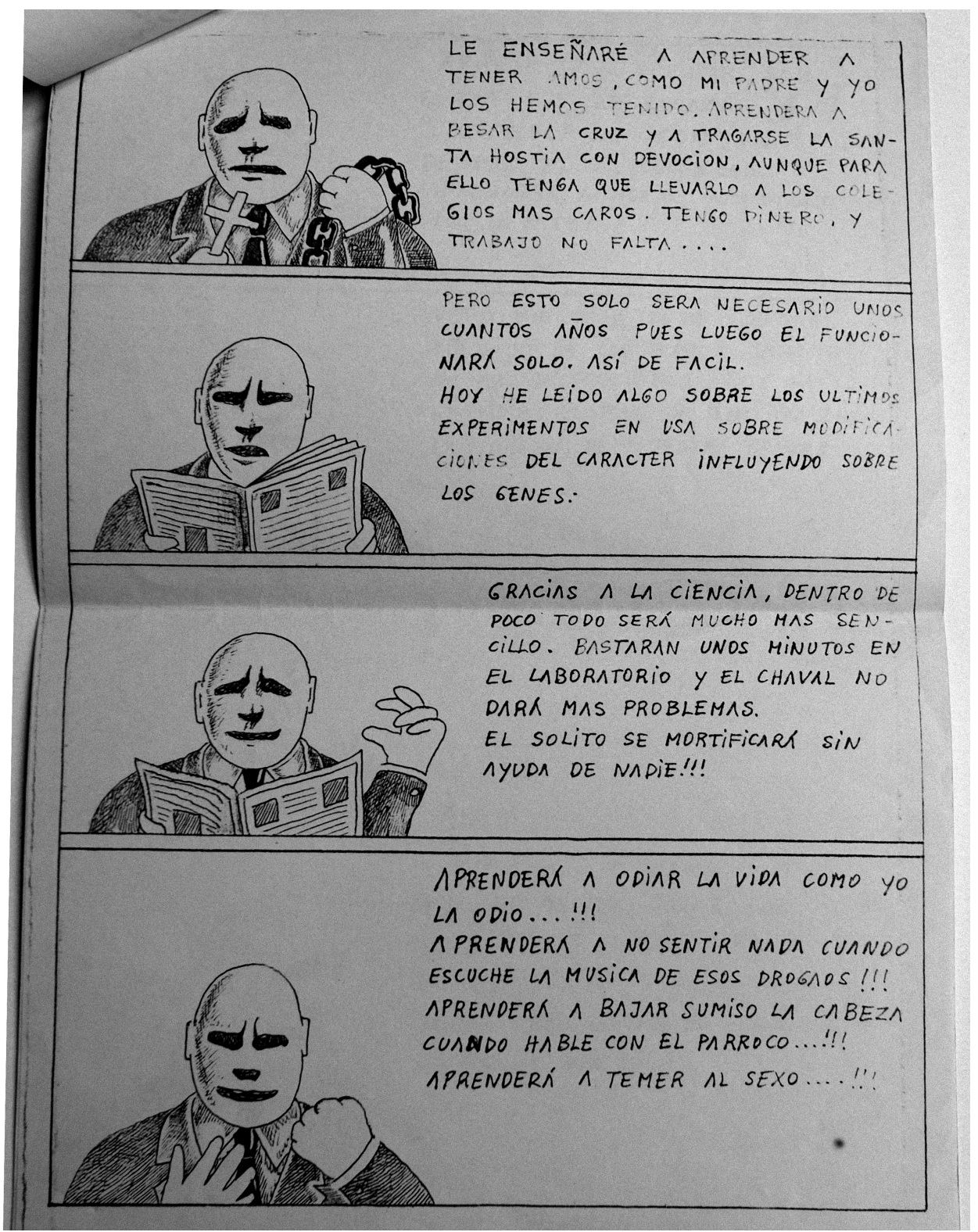

Fig. 15. Cascorro Factory, Rata, Madrid, 1977, archivo personal de Alberto García-Alix.

La calle madrileña cristaliza en la prensa marginal como un locus hostil, que sólo puede ser habitado de forma transitoria en los obligados desplazamientos por la ciudad. En el primer número de la revista $\mathrm{Mmm} . .$. ! (1976) encontramos un inquietante poema anónimo donde se relata un paseo nocturno por la ciudad, que culmina con lo que insinúa ser la detención del autor y la requisa de su cartera (fig. 16). Las letras blancas, despuntando sobre la página entintada de negro, se aparecen in crescendo, aumentando su tamaño y trazo a modo de grito de rabia o impotencia. Al mismo tiempo, el empleo de distintas tipografías manuales parecería apelar a una factura colectiva, llevada a cabo por distintas manos evidenciando, en último término, una experiencia también colectiva de la noche madrileña.

Esta experiencia furtiva de la calle, así como la del lugar común como refugio o abrigo, es recogida por la historieta "Metamorfosis", llevada a cabo por J.R. Ortega y aparecida en el ya comentado Carajillo 

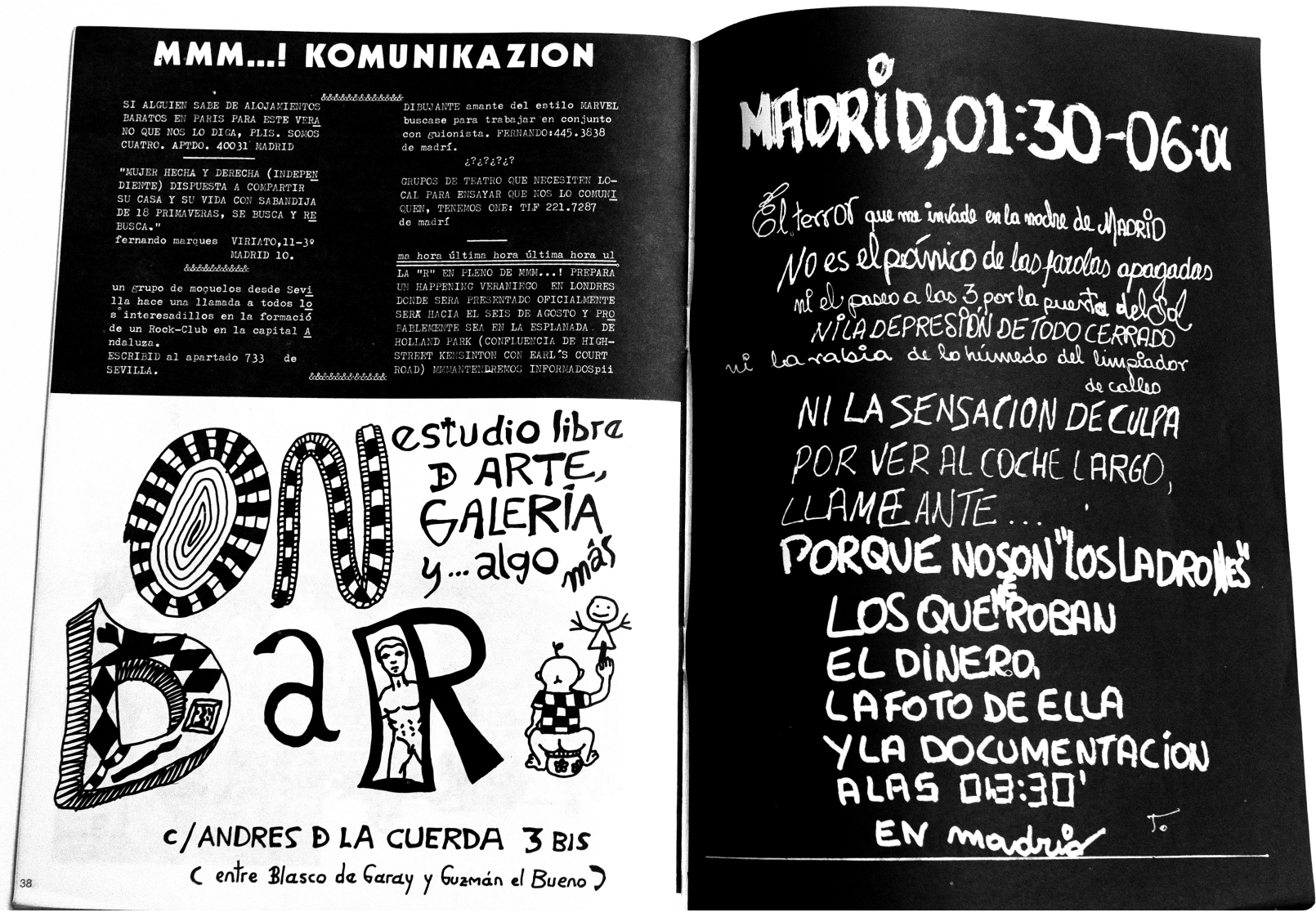

Fig. 16. Anónimo, "Madrid, 01:30-06:00”, Mmm..!! nº 1, Madrid, 1976, archivo personal de Alberto García-Alix.

(1975) (fig. 17). En ella se muestra la onírica transformación de un joven trajeado en una suerte de gnomo barbudo, que toma como escenario las solitarias calles de Madrid y su acogedor contrapunto, La Vaquería, uno de los primeros bares "modernos" de la capital ${ }^{47}$. En medio de un paisaje abigarrado, deformado y sucio, el exterior de La Vaquería se ofrece cálido y distendido a través de las numerosas figuras humanas que se encuentran al otro lado del cristal. La Vaquería fue fundada en el invierno de 1974 por un grupo de estudiantes y docentes de la Universidad Complutense de Madrid con el fin de abrir "un bar como los de Ibiza o Formentera", donde pudieran reunirse melenudos, artistas y militantes de distintas organizaciones "en la clandestinidad más festiva y carnavalera"48.

La construcción de espacios propios en la capital venía inevitablemente de la mano de la experiencia de la represión violenta. En la madrugada del 8 de junio de 1976, los Legionarios de Cristo Rey volaban por los aires la emblemática Vaquería con dos kilos de Goma-2, haciéndola desaparecer para siempre. La extinción o asesinato del local, su desaparición violenta, hace que esta se convierta en una suerte de icono de la disidencia madrileña, encontrando recurrentes referencias al mítico espacio en publicaciones poste-

\footnotetext{
47 Pepe Ribas señala en sus memorias, al respecto de La Vaquería, el ambiente de tensión que a veces reinaba en el local, ante la alarma producida por la llegada aleatoria de la policía, y añade: "Hoy, treinta años después, me pregunto por qué no describíamos en la revista lo que se vivía allí en 1975. Sólo me cabe una respuesta: por temor a que la policía o la ultraderecha utilizaran los escritos para acabar con lugares así”, en Pepe RiBAs, Los setenta a destajo; Ajoblanco y libertad, Barcelona, RBA, 2007, p. 391

48 Emilio SolA, La Vaquería de la Calle Libertad [en línea], http://sola.archivodelafrontera.com/pdf/vakeria_1976.pdf [Consulta: 16 de julio de 2018].
} 

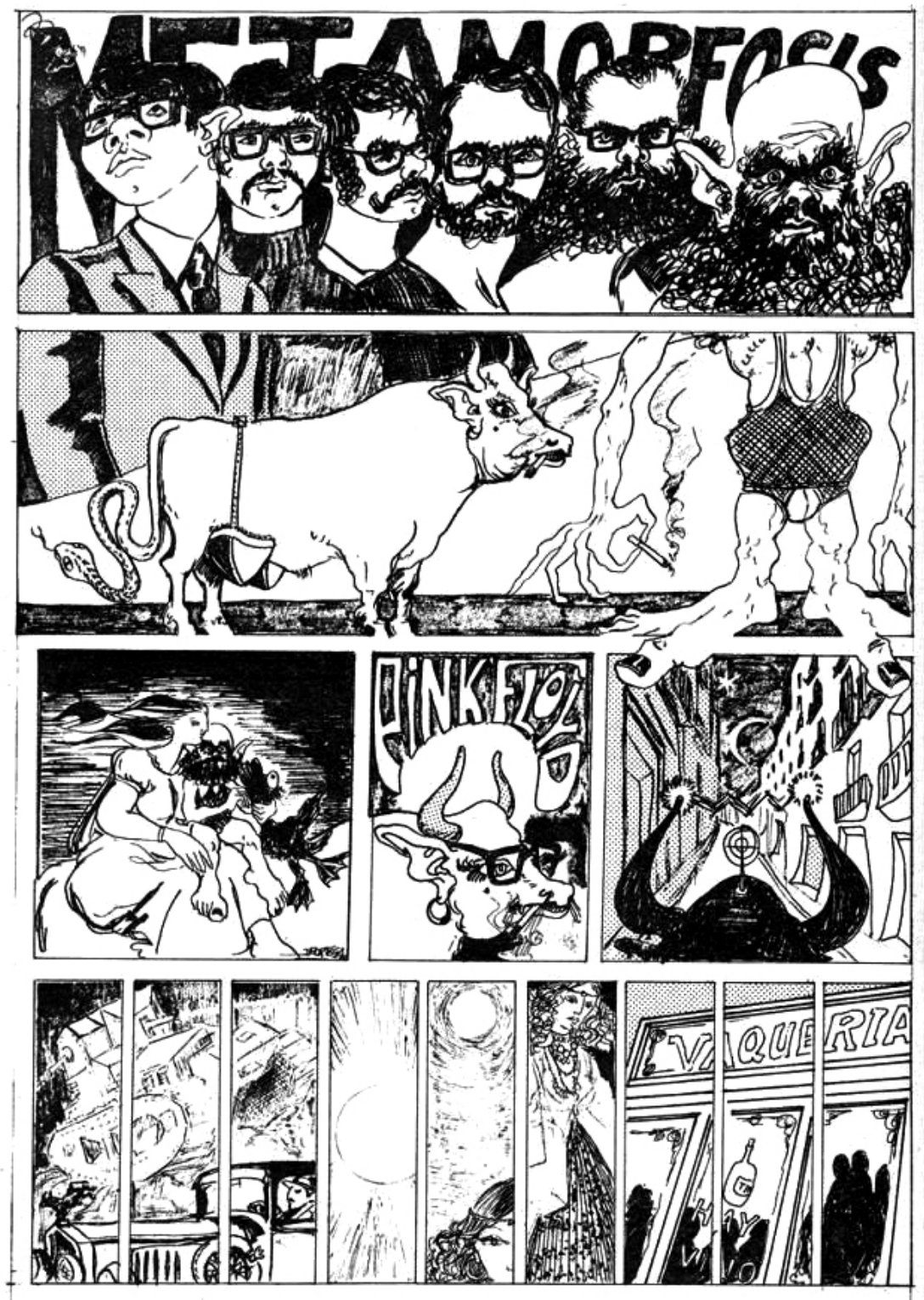

Fig. 17. J.R. Ortega, "Metamorfosis", Carajillo, Madrid, 1976, archivo personal de la autora.

riores. En la abigarrada y confusa editorial del número 5 de Mmmuá, titulada "Diktatorial. Opiniones de un muerto asesinado" (1977) hallamos una críptica referencia al bar ("La Vaquería está operada por muelles zerofáticos") en medio de lo que parece ser un paisaje literario-visual de impresiones acerca del clima represivo de la ciudad ("Aunque el diagnóstico descorazonadamente abúlico jamás nos produce tolerancia y síndrome de abstinencia”) (fig. 18).

Especialmente relevante para el estudio del Madrid marginal se revela la guía Mmmuá, surgida de la mano del Equipo Antípodas en enero de 1977 y cuya publicación se prolongó semanal o quincenalmente hasta el año 1978. Bajo el sugerente subtítulo "lo abyecto no ocupa lugar", el diminuto cuaderno se concretaba en un pliego de hojas tamaño cuartilla, dobladas y grapadas, que generalmente variaban su color en cada número, cuidando así el factor económico - apenas costaba cinco pesetas- y la discreción del portador, 


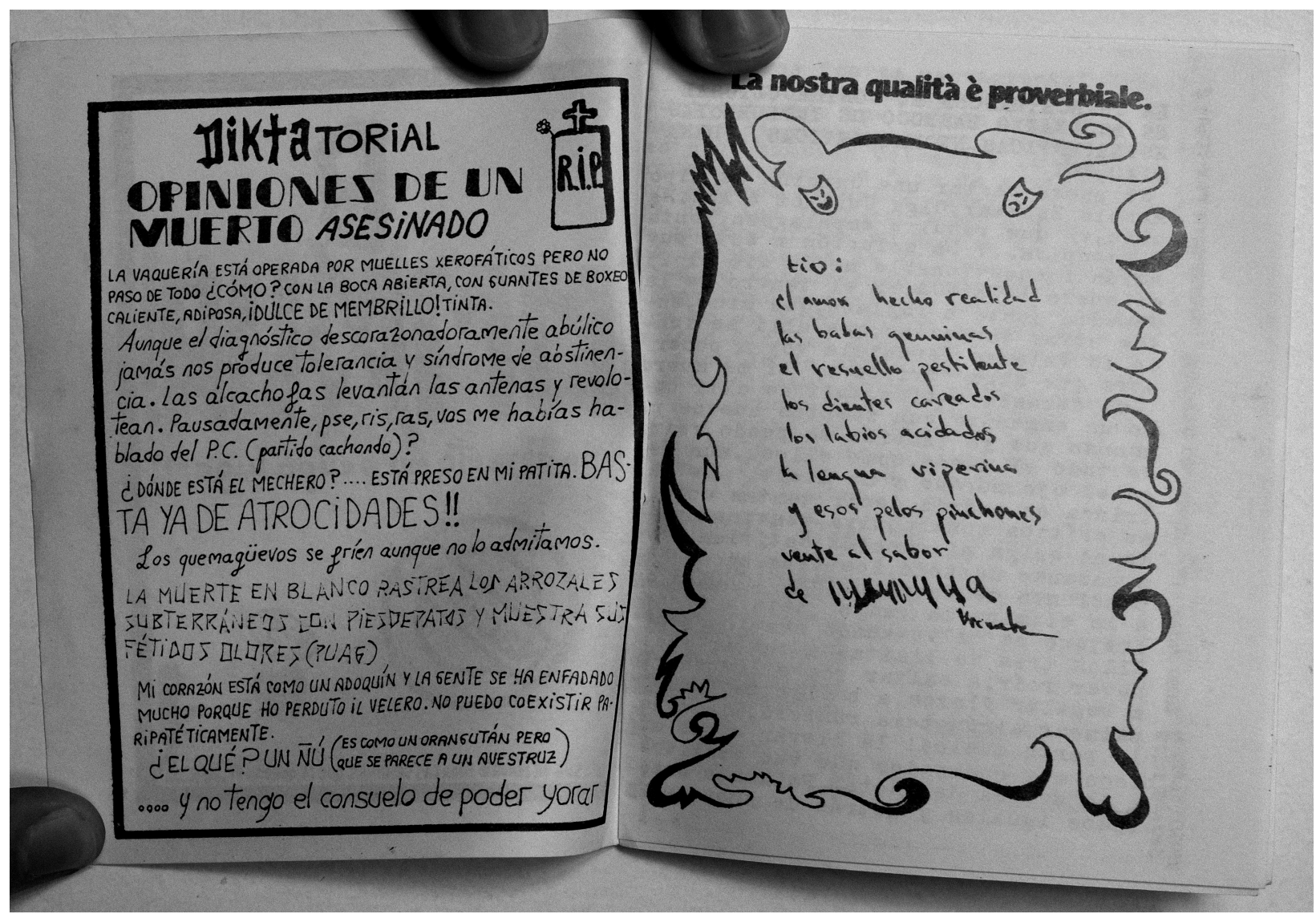

Fig. 18. Equipo Antípodas, “Diktatorial”, Mmmuá n³ 3, Madrid, 1977, archivo personal de Alberto García-Alix.

ya que podía ser escondido fácilmente. La guía intentaba "copar toda la actualidad subterránea de esta capital deliciosamente neurótica" 49 , encontrando en ella un amplio abanico de lugares e iniciativas, así como una interesante síntesis visual de la experiencia de la espacialidad marginal. Los contenidos, amontonados de forma abigarrada, respondían a una necesidad de rapidez y eficacia en la comunicación, que debía trasladar a los receptores toda la información posible acerca de los eventos y lugares sub de Madrid; así como imaginativas soluciones gráficas que apelaban a la diversidad y a la creatividad que caracterizaba a aquellos lugares. Es el caso del anuncio diseñado por El Zurdo para el Photocentro, fundado en 1975 por el equipo de la revista Nueva Lente ${ }^{50}$, en cuya imagen hallamos un onírico plano del edificio que pone de relieve la espacialidad "comunitaria" del lugar, que lega espacios para la reunión, como el bar o la galería; y traza exuberantes analogías con la idea de "jardín del conocimiento" (fig. 19).

\section{Papeles grapados para un mundo en común}

La prensa marginal pronto se reveló como catalizador de nuevas formas de organización. Cabe destacar, en este sentido, la experiencia comunitaria desarrollada por la Cascorro Factory hacia el final de 1976 en el piso de la Calle Encomienda: en permanente estado de ebullición, allí se prefiguró una suerte de proto-comuna cas-

\footnotetext{
49 Anónimo, “’Mmmuá!!’, una nueva guía del Madrid subterráneo”, El País (1977), s.n.

50 Entre ellos, Pablo Pérez-Mínguez, Carlos Serrano, Luis Garrido y Carlos Villasante.
} 


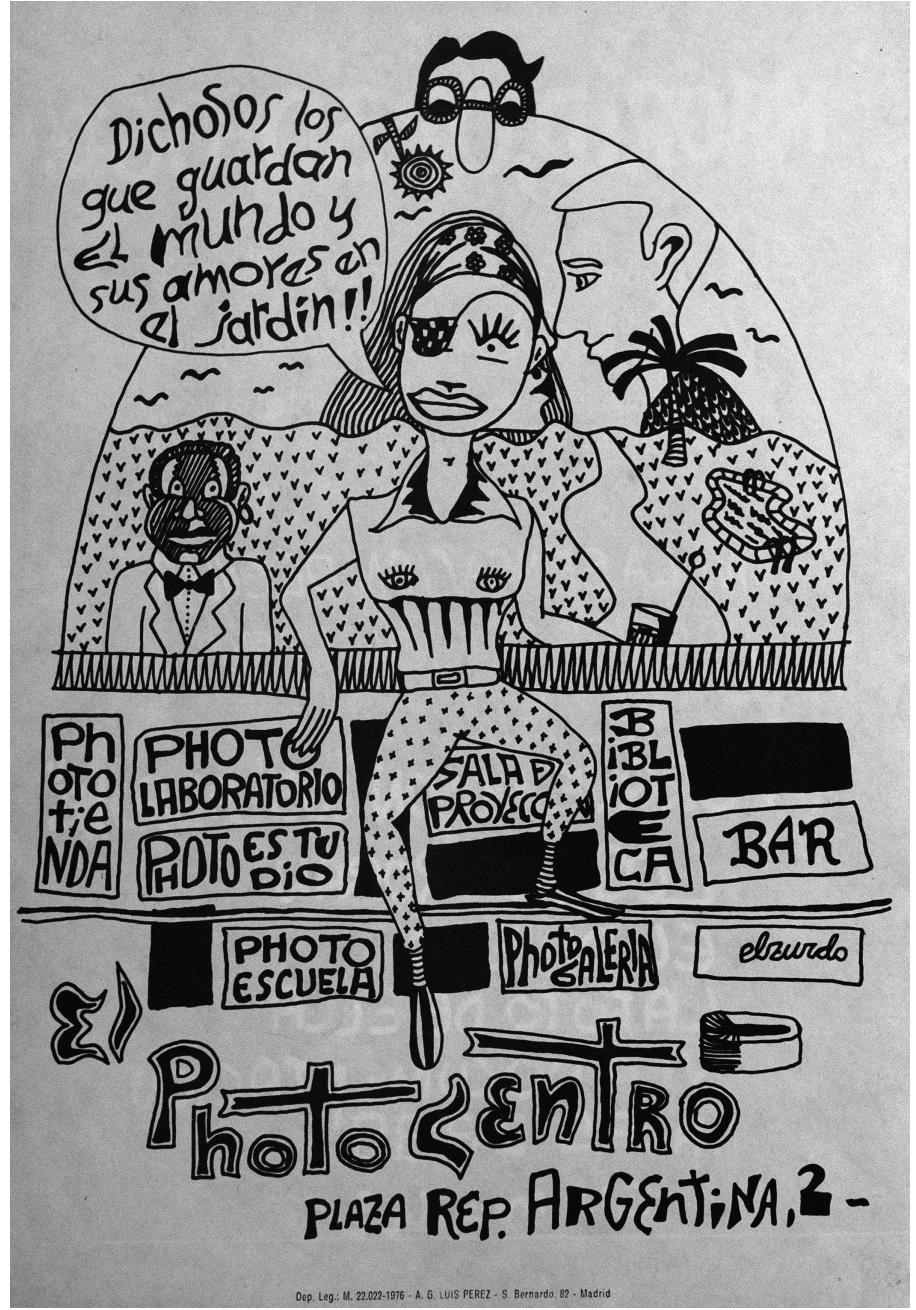

Fig. 19. El Zurdo, anuncio para "El Photocentro", Mmm..!! nº 1, Madrid, 1976, archivo personal de Alberto García-Alix.Mmтиá $\mathrm{n}^{\circ}$ 3, Madrid, 1977, archivo personal de Alberto García-Alix. tiza. Un grupo informe de jóvenes, vinculado directa o indirectamente con la Cascorry, comenzó a tejer una forma de vida comunitaria que buscaba destruir las relaciones de poder impresas en la institución familiar tradicional ${ }^{51}$. Fruto de aquella breve e intensa familia es el fanzine colectivo Burbujas de vida, compuesto por retratos gráficos de las personas que frecuentaron el apartamento, circulando entre ellas de mano en mano (fig. 20). Sobre un puñado de folios pentagramados, tomados como improvisado soporte, encontramos fotografías, ilustraciones, collages y poemas que hablan de los amigos de la Cascorro en un tono tierno y poético.

Los retratos se articulaban en torno a las fotografías realizadas por García-Alix, quien había recopilado una interesante crónica cotidiana de aquella vida en común a lo largo de aquel año. Junto a las fotografías, encontramos referencias elogiosas a la actitud vital distendida y creativa de cada una de las personas plasmadas, a modo de breves poemas: "¿No es cierto que impresiona la relajada tranquilidad de su actitud?", se preguntaba el autor anónimo, a propósito de un muchacho inglés que pasó algunos meses con el grupo. Y añade: "Carece de ambición. Actitud tan saludable que no ha podido ser asimilada por el medio ambiente en el que se desenvuelve". En tono epigramático y ambiguo, los versos se dispersan por las páginas con tipografías manuales muchas veces torpes, otras veces

enormemente expresivas, dependiendo de la habilidad de la persona que las realizase. Burbujas de vida nacía con la vocación de ser una práctica o ejercicio material común, articulador de simpatías y reconocimientos, en el efímero espacio comunitario construido en la buhardilla de la Calle Encomienda; lo que Pablo Carmona llama "el hecho comunitario":

El amor libre, los proyectos colectivos y las biografías grupales aparecieron como proyectos políticos centrales para poder trasladar el hecho revolucionario a la vida cotidiana. Y como consecuencia de todo ello nacieron las comunas urbanas y rurales ${ }^{52}$.

De esta forma, en las imágenes de Burbujas de vida encontramos las evidencias visuales de una fugaz autonomía afectiva y política, que tomaba el diseño gráfico espontáneo -el diseño gráfico que no se mira-

\footnotetext{
51 Sobre la alternativa comunal frente a la familia tradicional, véase Mario MAFFI, La cultura underground, Barcelona, Anagrama, 1975, p. 77.

52 CARmona, 2009, p. 148.
} 
ba a sí mismo como tal- como herramienta de comunicación interna a la comunidad. Al mismo tiempo, las iniciativas de comunicación marginal en Madrid también contestaron al creciente fenómeno de especialización técnico-profesional experimentado por los medios de comunicación durante los años 70, que comenzaban a cristalizar como el mecanismo de legitimación esencial para el proceso político de la Transición, y que buscaron articular instituciones propias, construidas colectivamente, donde todas las personas que participaran en ellas cumplieran muchas y distintas funciones, explorando sus capacidades expresivas con espontaneidad ${ }^{53}$. La prensa marginal buscaba emerger como un "único y gran organismo en manos de todos" 54 , un instrumento de ruptura contra el régimen de profesionalización impuesto por los procesos de modernización, que cercaba saberes, técnicas y experiencias. De esta forma, el surgimiento de las coordinadoras de prensa marginal, la Premamá (1976-1977) y La Cochu (1977-178), apuntaló el desarrollo de este tipo de experimentos comunicativos auto-organizados.

Las coordinadoras toman su punto de partida en uno de los debates celebrados en el Ateneo Politécnico a comienzos de 1977, los "Ciclos de sesudas habladurías", al hilo de una breve exposición realizada por Moncho Alpuente sobre el desarrollo de la free press estadounidense. En el conversatorio posterior, en el que participaron algunos miembros del Equipo Antípodas y del colectivo Bazofia, se esbozó la necesidad de generar una serie de estructuras comunitarias que apoyaran el tejido de la prensa marginal, convocando a las distintas publicaciones independientes de la ciudad. De esta manera, se agruparían las revistas Mmm..!, Bazofia, Cerrus, Acera, Catacumba y Alucinio en lo que será la primera coordinadora de prensa marginal madrileña: la Premamá. Como su propio nombre quería indicar - por otra parte, afortunado acrónimo de "prensa marginal madrileña"- la Premamá se encontraba en una fase pre-natal, y se articulaba en torno al "ansia de comunicar directamente su experiencia de vida" 55 .

El objetivo de Premamá era el de facilitar coordinación y apoyo económico a las precarias publicaciones que la integraban, así como establecer circuitos de distribución alternativos, horizontales, difundiendo los materiales en entornos "enrollados" como el Rastro o la Plaza Dos de Mayo a partir del establecimiento de vínculos con agrupaciones como la Cascorro Factory. Sin embargo, la aridez económica, social y política de la ciudad de Madrid hace que la experiencia de la Premamá se agote en la primavera de 1977, debido a la poca o inexistente solvencia económica del proyecto.

Ese verano la iniciativa era resucitada por algunas de las personas involucradas en la Premamá, como la dibujante Karmen, El Troyano o una jovencísima Alaska. Es entonces cuando aparece en El País un contundente artículo firmado por Moncho Alpuente, en el que declaraba el acta de nacimiento de una nueva coordinadora: "Premamá ha muerto, viva La Cochu"56. La Cochu, o los Laboratorios Colectivos Chueca, recuperan la estructura que la Premamá había desplegado en el entonces desaparecido Ateneo Politécnico, trasladándola al nuevo Ateneo ubicado en la calle Mantuano así como a la comuna que algunos de sus integrantes habían organizado en un ático ubicado en la Calle Libertad. Enrique Pardo, uno de sus integrantes, describía de esta forma el proceso de transformación de las coordinadoras:

En el principio había un conglomerado de gentes que proveníamos de diversos medios (prensa, FM, Ateneo Politécnico) que se reunió, como Equipo Antípodas, cuando hace dos años surgieron las primeras revistas marginales (Bazofia, Mmm...). La evolución duró un año, en el que aparecieron hasta veinte revistas de ese tipo (inclui-

\footnotetext{
53 Esto era explícitamente señalado en un artículo publicado en Ajoblanco a propósito de Premamá, que la consideraba “una experiencia deleznable para aquellos que creen que sólo pueden publicar papeles quienes ostentan el título oficial de periodistas -con carnet en regla, claro-, una montaña de dinero para invertir, gente profesional que emborronen de tópicos y modernidades sus páginas pagadas a mil y pico la holandesa escrita a máquina, y una imprenta técnicamente perfecta”. En José RIBAS, “Casa de 'maternidá' para una nueva prensa: Premamá”, Ajoblanco, n²1 (abril, 1977), p. 25.

54 VVAA, "La prensa marginal en su intimidad", Ajoblanco Extra "Prensa marginal”, s.n., 1978, p. 56.

55 RIBAS, 1977, p. 25.

56 Moncho AlPUENTE, "Premamá, coordinadora de revistas marginales, ha muerto" El País, (17 de julio de 1977), s.n.
} 


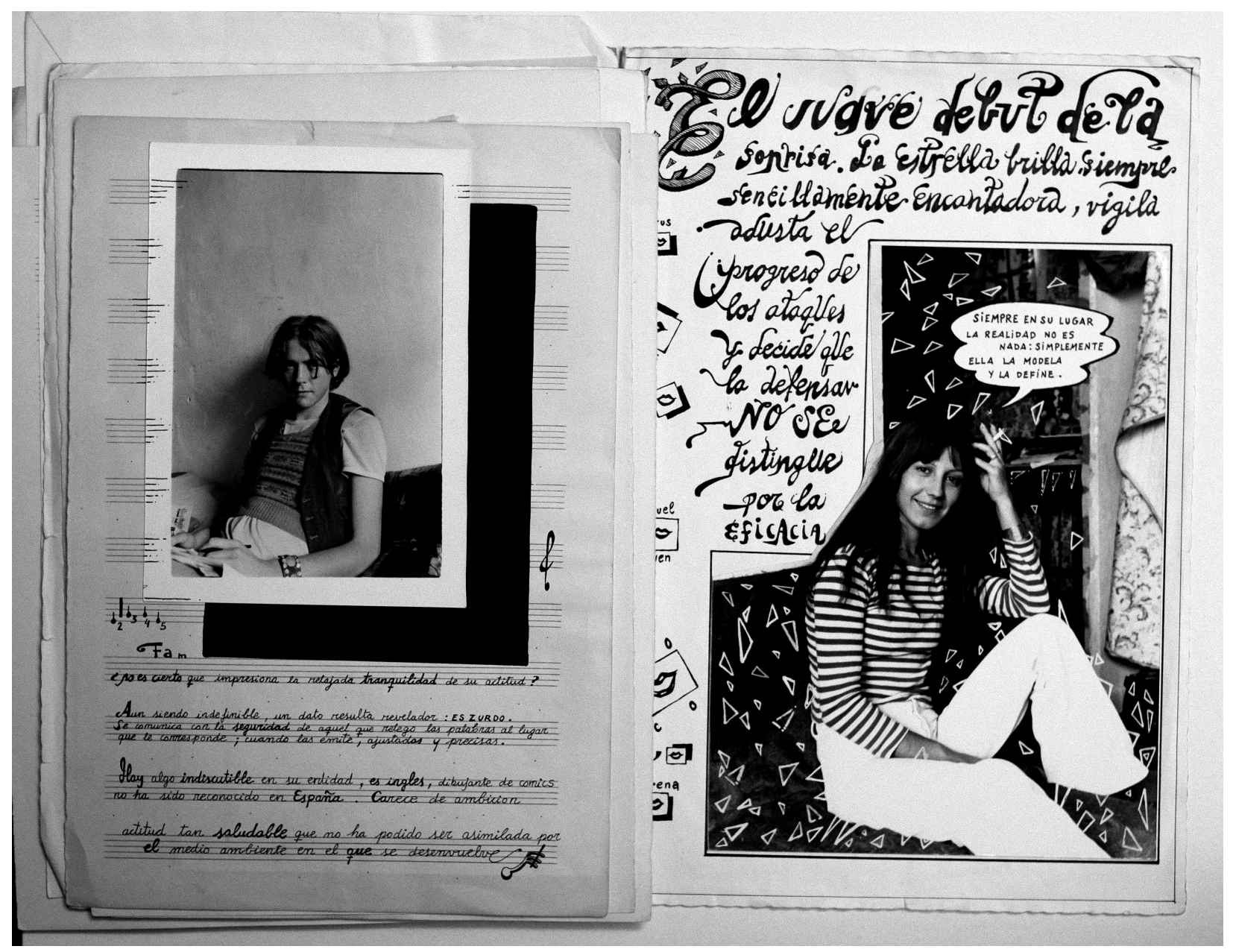

Fig. 20. Cascorro Factory, Burbujas de vida, Madrid, 1976, archivo personal de Alberto García-Alix.

da nuestra Mmmuá) y se creó la célebre Premamá (Prensa Marginal Madrileña), de tan corta existencia, ya que el escaso sentimiento colectivo de trabajo y lo esporádico de tales publicaciones imposibilitó la unión [...]. Premamá entró en crisis económica, lo mismo que Antípodas, y así vació (exigido por la imperiosa necesidad de pasta para el alquiler del local) un fortísimo sentimiento colectivo de unificación de cara a agrupar toda una serie de actividades con las que estábamos en diario contacto (música, teatro, etc.). Fue una evolución del grupo. Y en mayo del 77 surge La Cochu ${ }^{57}$.

El distintivo de La Cochu radicó, en este sentido, en la ampliación del rango de acción de la asociación. En abril de 1978, La Cochu abarcaba agrupaciones de música, teatro, cine -que en ese momento preparaba unas Jornadas de Súper 8-, un taller de Diseño Gráfico y Composición y se disponía a publicar dos revistas ${ }^{58}$. En este sentido, cabría destacar el éxito de la coordinadora en el terreno de la promoción musical que, a partir de la organización de conciertos - contando con bandas como Burning, Tequila o La Romántica Banda Local- logró proporcionar cierta liquidez económica al proyecto. Al mismo tiempo, la coordinadora había comenzado a tejer redes con iniciativas que se encontraban fuera de la capital, colabo-

\footnotetext{
57 Antonio DE Miguel, “Alguien conspira en la Corte”, Vibraciones, no 43 (abril, 1978), p. 31.

58 RIBAS, 1977, pp. 10-13.
} 
rando con Ajoblanco en la redacción de un número especial sobre la prensa marginal madrileña que aparecería publicado en el mes de octubre. Su objetivo era aglutinar manifestaciones, personas y actividades distintas en aras de esparcir un reguero de cultura disidente y autónoma, articulada en torno a los principios de solidaridad radical que caracterizaban a los movimientos antiautoritarios.

La experiencia de las coordinadoras verá su fin a lo largo de 1978, cuando el proceso político de la Transición comience a destensar los marcos jurídicos del régimen. A partir de la Ley para la Reforma Política (1977) y la consecuente supresión parcial del secuestro administrativo de publicaciones, la prensa antiautoritaria encontrará vías renovadas de comparecencia en el espacio público, diluyendo la marginalidad que las había caracterizado. En el último número de Bazofia, publicado a finales de 1977, el colectivo editorial vertía una lapidaria despedida:

Con este número acaba Bazofia. Por ella han pasado un montón de dibujantes, pero al cabo de un tiempo se dan cuenta de que están contando las mismas cosas, que el presupuesto es de miles de duros, por lo que la revista se encasillaría, comercializaría y perdería el encanto de sus primeros números, por eso acabamos con ella ${ }^{59}$.

La comercialización se imponía y la marginación voluntaria comenzaba a perder su razón de ser. En este sentido, las elecciones municipales de 1979 se revelaron como un punto de inflexión para el devenir de las publicaciones marginales: con la llegada de Tierno Galván a la alcaldía de Madrid se inicia el proceso de encumbramiento de la Movida madrileña, que descubrirá en la prensa marginal un provechoso fermento de imaginarios, prácticas y formas de vida singulares, ensalzando a figuras como Alberto GarcíaAlix, Ceespe, Alaska o las Costus. Como subraya Dopico, la prensa marginal madrileña ofrecía una "mitología gráfica provocadora que mostraba un espíritu de transgresión alegre y dotaba a la denuncia de originales tintes artísticos" ${ }^{\prime 60}$, que venía a solaparse con el deseo de renovar, dinamizar y activar la capital del Estado subyacente a las políticas culturales de Tierno Galván.

\section{Conclusiones}

A partir del examen de los materiales de la prensa marginal madrileña, este artículo ha desplegado las siguientes problemáticas:

1) La elaboración de una historiografía cívica de la Transición española desde los Estudios Visuales: en el presente trabajo se ha indagado en la experiencia destilada por las imágenes de la prensa marginal madrileña en tanto que índices visuales de un proyecto estético-político alternativo, que concreta modos de vida, acción y auto-organización singulares en el marco de la Transición española.

2) Los mass media y la imaginación política sesentayochista: al mismo tiempo, se ha buscado elaborar una composición historiográfica que adopte como punto de partida las reflexiones sobre los mass media alumbradas por el ciclo del 68 en distintos puntos geográficos. Los Mayos han sido comprendidos como un punto de ruptura en la esfera política y mediática global a partir de las mutaciones del capitalismo industrial, alentando la búsqueda de una "vida nueva" a partir de la movilización de una imaginación política vigorizada, que pretendía desbordar los marcos de la sociedad de consumo. El ciclo del 68, en la España de las décadas de los 60 y 70, se muestra en una doble vertiente emancipadora: respecto de la sociedad de consumo, de la que el país comenzaba a participar; y del régimen franquista y sus constreñidos marcos biopolíticos.

3) Los medios de comunicación contraculturales en la Transición española: por último, se ha invitado a profundizar en la reactualización de los análisis sobre la esfera mediática transicional tomando en cuen-

\footnotetext{
59 Colectivo Bazofia, "Editorial”, Bazofia, $\mathrm{n}^{\circ} 8$ ( 1977), s.n.

60 DopICO, 2005, p. 343.
} 
ta los medios de comunicación contraculturales que, en un principio, se negaron a ingresar en la esfera pública institucionalizada por el régimen, y que posibilitan la emergencia de estratos de experiencia histórica más matizados.

INÉS MOLINA AGUDO es graduada en Historia del Arte por la Universidad Complutense de Madrid y Máster en Historia del Arte Contemporáneo (MNCARS-UAM-UCM), apoyada por una beca de fomento a la investigación en la Universidad Autónoma de Madrid. Ha realizado estancias de estudios en la Université Rennes 2-Haute Bretagne y en la Universidad Nacional Autónoma de México, y se ha involucrado en distintos proyectos curatoriales y editoriales en colaboración con instituciones como el Museo Nacional Reina Sofía o el Musée des Beaux-Arts de Rennes. Sus líneas de investigación oscilan entre los análisis visuales y performativos de los movimientos sociales durante la Transición española, y la reflexión en torno a la memoria histórica en intersección con la teoría feminista.

Email: inmolinesca@gmail.com 